\title{
Natural and transboundary pollution influences on sulfate-nitrate-ammonium aerosols in the United States: Implications for policy
}

\section{Citation}

Park, Rokjin J., Daniel J. Jacob, Brendan D. Field, Robert M. Yantosca, and Mian Chin. 2004.

"Natural and Transboundary Pollution Influences on Sulfate-Nitrate-Ammonium Aerosols in the United States: Implications for Policy." Journal of Geophysical Research 109, issue D15.

\section{Published Version}

doi:10.1029/2003JD004473

\section{Permanent link}

http://nrs.harvard.edu/urn-3:HUL.InstRepos:14117811

\section{Terms of Use}

This article was downloaded from Harvard University's DASH repository, and is made available under the terms and conditions applicable to Other Posted Material, as set forth at http:// nrs.harvard.edu/urn-3:HUL.InstRepos:dash.current.terms-of-use\#LAA

\section{Share Your Story}

The Harvard community has made this article openly available.

Please share how this access benefits you. Submit a story.

\section{Accessibility}




\title{
Natural and transboundary pollution influences on sulfate-nitrate- ammonium aerosols in the United States: Implications for policy
}

\author{
Rokjin J. Park, Daniel J. Jacob, Brendan D. Field, and Robert M. Yantosca \\ Division of Engineering and Applied Sciences, Department of Earth and Planetary Sciences, Harvard University, \\ Cambridge, Massachusetts, USA \\ Mian Chin \\ NASA Goddard Space Flight Center, Greenbelt, Maryland, USA
}

Received 20 December 2003; revised 21 May 2004; accepted 3 June 2004; published 12 August 2004.

[1] We use a global three-dimensional coupled oxidant-aerosol model (GEOS-CHEM) to estimate natural and transboundary pollution influences on sulfate-nitrate-ammonium aerosol concentrations in the United States. This work is motivated in part by the Regional Haze Rule of the U.S. Environmental Protection Agency (EPA), which requires immediate action to improve visibility in U.S. wilderness areas along a linear trajectory toward an endpoint of "natural visibility conditions" by 2064 . We present full-year simulations for 1998 and 2001 and evaluate them with nationwide networks of observations in the United States and Europe (Interagency Monitoring of Protected Visual Environments (IMPROVE), Clean Air Status and Trends Network (CASTNET), National Atmospheric Deposition Program (NADP), European Monitoring and Evaluation Programme (EMEP)) and with Asian outflow observations from the NASA Transport and Chemical Evolution over the Pacific (TRACE-P) aircraft mission. Shutting off U.S. anthropogenic emissions in the model defines "background" aerosol concentrations representing contributions from both natural and transboundary pollution sources. We find that transboundary transport of pollution from Canada, Mexico, and Asia dominates over natural influences for both sulfate and nitrate. Trans-Pacific transport of Asian pollution accounts for $30 \%$ of background sulfate in both the western and eastern United States. Our best estimates of natural concentrations for ammonium sulfate and ammonium nitrate in the United States are either consistent with or lower than the default values recommended by EPA for natural visibility calculations. However, the large transboundary pollution influence in our calculation suggests that a natural visibility objective cannot be approached without international emission controls. INDEX TERMS: 0305 Atmospheric Composition and Structure: Aerosols and particles (0345, 4801); 0368 Atmospheric Composition and Structure: Troposphere - constituent transport and chemistry; 0345 Atmospheric Composition and Structure: Pollution - urban and regional (0305); KEYWORDS: trans-Pacific transport, Asian pollution, aerosols

Citation: Park, R. J., D. J. Jacob, B. D. Field, R. M. Yantosca, and M. Chin (2004), Natural and transboundary pollution influences on sulfate-nitrate-ammonium aerosols in the United States: Implications for policy, J. Geophys. Res., 109, D15204, doi:10.1029/2003JD004473.

\section{Introduction}

[2] Visibility degradation in the United States is mostly due to fine aerosols [Malm et al., 2000] including carbonaceous (elemental and organic), sulfate, nitrate, and soil dust components. These aerosols originate from both anthropogenic and natural sources. The U.S. Environmental Protection Agency (EPA) Regional Haze Rule [United States Environmental Protection Agency (U.S. $E P A), 2003$ ] mandates a schedule of increasing emission controls to achieve "natural visibility conditions" in national parks and other wilderness areas of the United

Copyright 2004 by the American Geophysical Union. 0148-0227/04/2003JD004473\$09.00
States by 2064. Defining this natural visibility endpoint requires better information on natural aerosol concentrations and on the perturbing effects from transboundary transport of anthropogenic pollution. We previously examined this issue in a global three-dimensional (3-D) model simulation of carbonaceous aerosols [Park et al., 2003] and found that quantification of wildfire emissions was of critical importance. Transboundary transport of anthropogenic pollution was relatively unimportant for carbonaceous aerosols because of the large natural sources from wildfires and vegetation. We apply here the same analysis to sulfate and nitrate aerosols, which are other important components of visibility degradation and hence prime targets for regulation. As we will see, transboundary transport of pollution including interconti- 
nental transport from Asia emerges in this case as a critical concern.

[3] The main sources of sulfate and nitrate aerosols are atmospheric oxidation of $\mathrm{SO}_{2}$ and nitrogen oxides $\left(\mathrm{NO}_{x} \equiv\right.$ $\mathrm{NO}+\mathrm{NO}_{2}$ ) to $\mathrm{H}_{2} \mathrm{SO}_{4}$ and $\mathrm{HNO}_{3}$, respectively (information available from NARSTO at http://www.cgenv.com/ Narsto/). Fossil fuel combustion is the dominant source of $\mathrm{SO}_{2}$ and $\mathrm{NO}_{x}$ in the United States. Important natural sources include volcanoes and atmospheric oxidation of oceanic dimethyl sulfide (DMS) for $\mathrm{SO}_{2}$, and lightning, soils, and wildfires for $\mathrm{NO}_{x}$. The low vapor pressure of $\mathrm{H}_{2} \mathrm{SO}_{4}$ over $\mathrm{H}_{2} \mathrm{SO}_{4}-\mathrm{H}_{2} \mathrm{O}$ solutions implies that all of sulfate is in the aerosol phase. The sulfate aerosols can be partly or totally neutralized by ammonia $\left(\mathrm{NH}_{3}\right)$ emitted from livestock, fertilizer use, and other less important sources. If excess ammonia is available beyond that required for sulfate neutralization to ammonium sulfate $\left(\mathrm{NH}_{4}\right)_{2} \mathrm{SO}_{4}$, then ammonium nitrate $\left(\mathrm{NH}_{4} \mathrm{NO}_{3}\right)$ aerosol can form; otherwise, and except for cloudy conditions, nitric acid remains in the gas phase. This simple $\mathrm{H}_{2} \mathrm{SO}_{4}-\mathrm{HNO}_{3}-\mathrm{NH}_{3}$ thermodynamic framework provides a remarkably successful general description of sulfate and nitrate aerosols in the United States [Seinfeld and Pandis, 1998]. Sulfate and nitrate can also be incorporated in soil dust or sea salt particles, but these contributions appear to be significant only in desert and coastal areas.

[4] Transboundary transport of pollution could compromise the objective of natural visibility in the Regional Haze Rule. We define here an aerosol "background" following U.S. EPA (manuscript in preparation, 2003) as the aerosol concentration that would be present over the United States in the absence of domestic anthropogenic emissions. It includes contributions from natural sources but also from transboundary transport of pollution. If the latter are significant, then a natural visibility objective can be approached only through international emission controls. Alternatively, one should replace this objective by a "background visibility" objective that allows for uncontrollable emissions outside U.S. borders.

[5] Intercontinental transport of Asian pollution is of particular interest for our study. Previous studies have shown that Asian pollution makes a significant (26 ppbv) contribution to background ozone concentrations in surface air in the United States [Berntsen et al., 1999; Jacob et al., 1999; Fiore et al., 2002], principally by enhancing the Northern Hemispheric ozone background [Fiore et al., 2003b]. Export and trans-Pacific transport of Asian aerosol pollution is expected to be far less efficient than for ozone because the lifting of Asian air to the free troposphere involves wet processes (convection, warm conveyor belts) [Liu et al., 2003] that scavenge aerosols with high efficiency [Koike et al., 2003]. Most previous studies of trans-Pacific transport of aerosols have focused on dust events, where the Asian source is very large and the lifting to the free troposphere takes place by dry processes [Husar et al., 2001; McKendry et al., 2001; Vaughan et al., 2001]. However, Jaffe et al. [1999, 2003] and Bertschi et al. [2004] also showed significant aerosol enhancements in Asian pollution plumes sampled over the West Coast of the United States in spring. As we will see, our model results suggest that trans-Pacific Asian pollution is a major contributor to the sulfate background over the United States on an annual average basis.

\section{Model Description}

\subsection{General Description}

[6] We use the GEOS-CHEM chemical transport model [Bey et al., 2001a] to conduct full-year simulations for 1998 and 2001 of the sulfate-nitrate-ammonium inorganic aerosol system coupled to oxidant chemistry. Most of our analysis focuses on the 2001 simulation. The 1998 simulation is used for evaluation with European observations, as 2001 observations were not available in a timely manner. The GEOS-CHEM model (version 5.03, http://www-as.harvard. edu/chemistry/trop/geos) uses assimilated meteorological data from the NASA Goddard Earth Observing System (GEOS), including winds, convective mass fluxes, mixed layer depths, temperature, clouds, precipitation, and surface properties. Meteorological data for 1998 and 2001 are available with 6-hour temporal resolution (3-hour resolution for surface variables and mixing depths), $1^{\circ}$ latitude by $1^{\circ}$ longitude $\left(1^{\circ} \times 1^{\circ}\right)$ horizontal resolution, and 48 sigma vertical layers. We degrade the horizontal resolution to $2^{\circ} \times$ $2.5^{\circ}$ for computational expediency. The lowest model levels are centered at $\sim 10,50,100,200,400,600,900,1200$, and $1700 \mathrm{~m}$ above the local surface.

[7] The GEOS-CHEM simulation of tropospheric oxidant chemistry includes a detailed ozone- $\mathrm{NO}_{x}$-hydrocarbon chemical mechanism ( $\sim 80$ species, $\sim 300$ reactions). Results from this simulation have been reported in a number of papers [Bey et al., 2001a, 2001b; Li et al., 2001, 2002a, 2002b; Liu et al., 2002; Martin et al., 2002] including focused studies of surface ozone in North America and North American outflow [Fiore et al., 2002, 2003a, 2003b; Li et al., 2004]. GEOS-CHEM simulations of aerosols have been reported previously for radionuclides [Liu et al., 2001] and carbonaceous species [Park et al., 2003]. The $\mathrm{H}_{2} \mathrm{SO}_{4}-\mathrm{HNO}_{3}-\mathrm{NH}_{3}$ aerosol simulation is a new capability for GEOS-CHEM and is described in more detail below. The aerosol and oxidant simulations are coupled through formation of sulfate and nitrate, $\mathrm{HNO}_{3}(\mathrm{~g}) / \mathrm{NO}_{3}^{-}$partitioning of total inorganic nitrate, heterogeneous chemistry [Jacob, 2000], and aerosol effects on photolysis rates [Martin et al., 2003]. Partitioning of total ammonia and nitric acid between the gas and aerosol phases is calculated using the MARS-A thermodynamic equilibrium model [Binkowski and Roselle, 2003].

[8] The wet deposition scheme for aerosols is described by Liu et al. [2001]. It includes contributions from scavenging in convective updrafts, rainout and washout from convective anvils and large-scale precipitation, and it allows for return to the atmosphere following evaporation. We extend it here to soluble gases on the basis of their effective Henry's law partitioning in warm clouds, retention efficiency upon droplet freezing in mixed clouds, and surface coating or cocondensation of ice crystals in cold clouds [Mari et al., 2000]. Scavenging of $\mathrm{SO}_{2}$ is limited by the local availability of $\mathrm{H}_{2} \mathrm{O}_{2}$ as a fast aqueous-phase oxidant converting $\mathrm{SO}_{2}$ to sulfate [Chin et al., 1996, 2000a]. Dry deposition of aerosols and gases uses a standard resistance-in-series model dependent on local surface type and meteorological 
conditions [Wesely, 1989] and implemented as described by Wang et al. [1998].

[9] We conducted five different simulations for 2001, including one standard simulation as described above, and four sensitivity simulations excluding anthropogenic emissions (1) globally, (2) in the United States, (3) in North America, and (4) in Asia. From these we quantify the influences of natural, transboundary, and intercontinental pollution sources on sulfate-nitrate-ammonium aerosol concentrations in the United States.

[10] Each simulation was carried out as follows. We first conducted a fully coupled oxidant-aerosol simulation at $4^{\circ} \times$ $5^{\circ}$ horizontal resolution for computational expediency. Oxidant concentration fields $\left(\mathrm{OH}, \mathrm{O}_{3}, \mathrm{NO}_{3}\right), \mathrm{H}_{2} \mathrm{O}_{2}$ production rates, photolysis frequencies, and total inorganic nitrate concentrations (gas-phase nitric acid plus aerosol nitrate) were archived from this simulation and used to conduct an aerosol-only simulation at finer $2^{\circ} \times 2.5^{\circ}$ horizontal resolution. The aerosol-only simulation includes nine prognostic chemical species: DMS, $\mathrm{SO}_{2}$, sulfate, methanesulfonic acid (MSA), $\mathrm{HNO}_{3}(\mathrm{~g}), \mathrm{NO}_{3}^{-}, \mathrm{NH}_{3}(\mathrm{~g}), \mathrm{NH}_{4}^{+}$, and $\mathrm{H}_{2} \mathrm{O}_{2}$. The 2001 and 1998 simulations were initialized on 1 October 2000 and 1 October 1997, respectively, and conducted for 15 months. The first 3 months were used to achieve proper initialization, and we focus our attention on the following 12 months.

\subsection{Sulfur Simulation}

[11] The sulfur simulation in GEOS-CHEM is based on the Georgia Tech/Goddard Global Ozone Chemistry Aerosol Radiation and Transport (GOCART) model [Chin et al., 2000a], with a number of modifications described below. Our fossil fuel and industrial emission inventory is for 1999-2000 and is obtained by scaling the gridded, seasonally resolved inventory from the Global Emissions Inventory Activity (GEIA) for 1985 [Benkovitz et al., 1996] with updated national emission inventories and fuel use data [Bey et al., 2001a]. The emissions for the United States and Canada are from U.S. EPA [2001], and the emissions for European countries are from European Monitoring and Evaluation Programme (EMEP)/United Nations Economic Commission for Europe (UNECE) (data available from UNECE/EMEP activity data and emission database at http://webdab.emep.int). Asian sulfur emission in the model is $20 \mathrm{Tg} \mathrm{S} \mathrm{yr}{ }^{-1}$, which can be compared to year 2000 estimates of $17 \mathrm{Tg} \mathrm{S} \mathrm{yr}^{-1}$ by Streets et al. [2003] and $25 \mathrm{Tg}$ $\mathrm{S} \mathrm{yr}^{-1}$ by Intergovernmental Panel on Climate Change (hereinafter IPCC) [2001]. Anthropogenic sulfur is emitted as $\mathrm{SO}_{2}$ except for a small fraction as sulfate (5\% in Europe and 3\% elsewhere) [Chin et al., 2000a].

[12] Other anthropogenic sources of $\mathrm{SO}_{2}$ in the model include gridded monthly aircraft emissions $\left(0.07 \mathrm{Tg} \mathrm{S} \mathrm{yr}^{-1}\right)$ taken from Chin et al. [2000a] and biofuel use. We use a global biofuel $\mathrm{CO}$ emission inventory with $1^{\circ} \times 1^{\circ}$ spatial resolution from Yevich and Logan [2003] and apply an emission factor of $0.0015 \mathrm{~mol} \mathrm{SO}_{2}$ per mole $\mathrm{CO}$ [Andreae and Merlet, 2001]. Seasonal variations in biofuel emissions are specified from the heating degree days approach [Park et al., 2003].

[13] Natural sources of sulfur in the model include DMS from oceanic phytoplankton and $\mathrm{SO}_{2}$ from volcanoes and biomass burning. The oceanic emission of DMS is calcu-
Table 1a. Sulfur Emissions for $2001^{a}$

\begin{tabular}{lcc}
\hline \multicolumn{1}{c}{ Source Type } & Globe & $\begin{array}{c}\text { Contiguous } \\
\text { United States }\end{array}$ \\
\hline Total & 78 & 8.3 \\
Anthropogenic source total & 57 & 8.3 \\
Industrial activity & 56 & 8.3 \\
Biofuel use & 0.27 & $<0.01$ \\
Aircraft & 0.07 & 0.02 \\
Natural source total & 21 & 0.01 \\
Ocean (DMS) & 15 & 0 \\
Volcanoes & 4.8 & 0 \\
Biomass burning & 1.3 & 0.01 \\
\hline
\end{tabular}

${ }^{\mathrm{a}}$ Emissions are in $\mathrm{Tg} \mathrm{S} \mathrm{yr}^{-1}$.

lated as the product of local seawater DMS concentration and sea-to-air transfer velocity. The seawater DMS concentrations are gridded monthly averages from Kettle et al. [1999], and the transfer velocity of DMS is computed using an empirical formula from Liss and Merlivat [1986] as a function of the surface $(10 \mathrm{~m})$ wind speed. The GEOS surface winds used here assimilate remote sensing data from the Special Sensor Microwave Imager instrument. Volcanic emissions of $\mathrm{SO}_{2}$ from continuously active volcanoes are included from the database of Andres and Kasgnoc [1998]. Emissions from sporadically erupting volcanoes show large year-to-year variability and are not included in the model. No major volcanic eruptions occurred in 2001. Biomass burning emissions of $\mathrm{SO}_{2}$ are calculated using a gridded monthly biomass burning inventory of $\mathrm{CO}$ constrained from satellite observations in 2001 by Duncan et al. [2003] with an emission factor of $0.0026 \mathrm{~mol} \mathrm{SO}_{2}$ per mole $\mathrm{CO}$ [Andreae and Merlet, 2001].

[14] Table 1a summarizes global and contiguous U.S. (excluding Alaska and Hawaii) sulfur emissions for 2001. The United States contributes $10 \%$ of the global source (15\% of the global anthropogenic source). Natural sources contribute $27 \%$ globally and are negligible within the contiguous United States.

[15] The gas-phase sulfur oxidation chemistry in the model includes DMS oxidation by $\mathrm{OH}$ to form $\mathrm{SO}_{2}$ and MSA, DMS oxidation by nitrate radicals $\left(\mathrm{NO}_{3}\right)$ to form $\mathrm{SO}_{2}$, and $\mathrm{SO}_{2}$ oxidation by $\mathrm{OH}$ to form sulfate. Reaction rates are from DeMore et al. [1997] and the yields of $\mathrm{SO}_{2}$ and MSA from DMS oxidation are from Chatfield and Crutzen [1990]. Aqueous-phase oxidation of $\mathrm{SO}_{2}$ by $\mathrm{O}_{3}$ and $\mathrm{H}_{2} \mathrm{O}_{2}$ in clouds to form sulfate is included using kinetic data from $\mathrm{Jacob}$ [1986] and assuming a $\mathrm{pH}$ of 4.5 for the oxidation by $\mathrm{O}_{3}$. Cloud liquid water content is not available in the GEOS data, and we specify it instead in each cloudy grid box by using a temperature-dependent parameterization [Somerville and Remer, 1984]. The cloud volume fraction in a given grid box is specified as an empirical function of the relative humidity following Sundqvist et al. [1989].

\subsection{Ammonia Simulation}

[16] Ammonia emissions in the model are based on annual data for 1990 from the $1^{\circ} \times 1^{\circ}$ GEIA inventory of Bouwman et al. [1997]. Source categories in that inventory include domesticated animals, fertilizers, human bodies, industry, fossil fuels, oceans, crops, soils, and wild animals. We view the first five as anthropogenic and the last four as natural. Additional emissions from biomass burning and biofuel use are computed using the global inventories of 
Table 1b. Ammonia Emissions for $2001^{\mathrm{a}}$

\begin{tabular}{lcc}
\hline \multicolumn{1}{c}{ Source Type } & Globe & $\begin{array}{c}\text { Contiguous } \\
\text { United States }\end{array}$ \\
\hline Total & 55 & 2.8 \\
Anthropogenic source total & 35 & 2.2 \\
Domesticated animals & 21 & 1.3 \\
Fertilizers & 9.0 & 0.49 \\
Human bodies & 2.6 & 0.13 \\
Biofuel use & 1.6 & 0.18 \\
Industry & 0.2 & 0.03 \\
Fossil fuel use & 0.1 & 0.06 \\
Natural source total & 20 & 0.59 \\
Ocean & 8.2 & 0 \\
Biomass burning & 5.9 & 0.04 \\
Crop & 3.5 & 0.44 \\
Soil & 2.4 & 0.1 \\
Wild animals & 0.1 & 0.01 \\
\hline
\end{tabular}

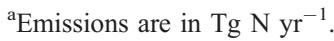

Duncan et al. [2003] and Yevich and Logan [2003], with an emission factor of $1.3 \mathrm{~g} \mathrm{NH}_{3}$ per kilogram dry mass burned [Andreae and Merlet, 2001]. The resulting total annual source of ammonia for the United States is reduced by $10 \%$ to match that derived by Gilliland et al. [2003] from an inverse model analysis of monthly precipitation chemistry $\left(\mathrm{NH}_{4}^{+}\right)$data.

[17] Table $1 \mathrm{~b}$ shows a summary of global and contiguous U.S. ammonia emissions for 2001. The United States accounts for $5 \%$ of the global source $(6 \%$ of the global anthropogenic source). Natural sources amount to $37 \%$ of global ammonia emissions and $21 \%$ of contiguous U.S. emissions.

[18] Several ammonia sources in Table $1 \mathrm{~b}$ have strong seasonal variations. For the emissions from domesticated animals and soils, we use exponential dependences on temperature reported by Aneja et al. [2000] and Roelle and Aneja [2002], respectively. Ammonia emissions from crops and fertilizers are assumed to vary seasonally with the number of daylight hours [Adams et al., 1999]. Seasonal variations in biomass burning and biofuel emissions are specified from satellite observations [Duncan et al., 2003] and the heating degree days approach [Park et al., 2003],

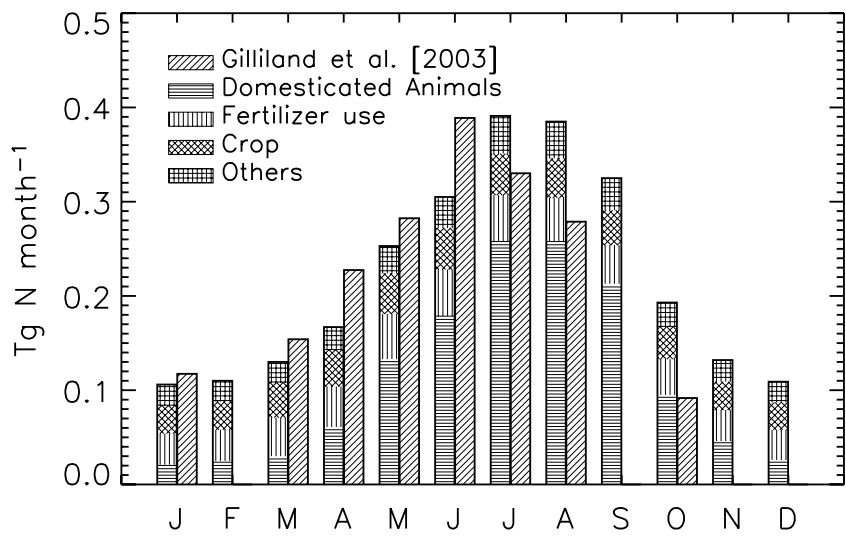

Figure 1. Monthly ammonia emissions in the contiguous United States. The values used in this work, broken down by source type (left bars), are compared to the values reported by Gilliland et al. [2003] (right bars) from inverse modeling of 8 months of precipitation $\mathrm{NH}_{4}^{+}$data. respectively. Figure 1 shows the resulting seasonal variation of ammonia emission in the United States. The summer maximum is driven mainly by domesticated animals. Compared to the results of the Gilliland et al. [2003] inverse model analysis, also shown in Figure 1, our seasonal cycle lags in phase by $1-2$ months, and emission in October is a factor of 2 higher.

\subsection{Nitrate Simulation}

[19] Production of total inorganic nitrate (gas-phase nitric acid and aerosol nitrate) in the model is computed from the ozone- $\mathrm{NO}_{x}$-hydrocarbon chemical mechanism (see section 2.1). Table 1c gives a summary of global and contiguous U.S. $\mathrm{NO}_{x}$ emissions; details on these sources are from Bey et al. [2001a] and Martin et al. [2002]. The United States accounts for $17 \%$ of global emissions $(25 \%$ of global anthropogenic emissions). Natural sources from lightning, soils, and biomass burning account for $38 \%$ of global emissions and $9 \%$ in the contiguous United States.

\subsection{Global Budgets}

[20] Tabulated summaries of the global sulfate, nitrate, and ammonium aerosol budgets in GEOS-CHEM are given by Martin et al. [2004], who applied the model to an investigation of phase transition effects on aerosol radiative forcing. The global sulfate, nitrate, and ammonium burdens for 2001 are $0.40 \mathrm{Tg} \mathrm{S}, 0.07 \mathrm{Tg} \mathrm{N}$, and $0.32 \mathrm{Tg} \mathrm{N}$, respectively. The lifetimes against deposition are 3.9, 3.2, and 3.8 days, respectively. Wet deposition accounts for $80-$ $90 \%$ of total deposition.

[21] Our global sulfate burden is lower than those $(0.54-$ $1.03 \mathrm{Tg} \mathrm{S}$ ) from models that participated in the comparison of large-scale atmospheric sulfate aerosol models (COSAM) [Barrie et al., 2001]. Our anthropogenic emission (57 Tg S $\left.\mathrm{yr}^{-1}\right)$ is lower than that used in COSAM $\left(67 \mathrm{Tg} \mathrm{S} \mathrm{yr}^{-1}\right)$ because our emission inventory is for 1999-2000 (versus 1985 in COSAM) and accounts for emission reductions in Europe (by $61 \%$ since 1985) and the United States (by $22 \%$ since 1985). The major natural sulfur sources in our model from oceans $\left(15 \mathrm{Tg} \mathrm{S} \mathrm{yr}^{-1}\right)$ and volcanoes $\left(5 \mathrm{Tg} \mathrm{S} \mathrm{yr}^{-1}\right)$ are also lower than those used in COSAM (29 and $10 \mathrm{Tg} \mathrm{S} \mathrm{yr}^{-1}$, respectively). These natural sources contribute disproportionately to the global atmospheric sulfate burden because their sulfur can be delivered efficiently to the free troposphere where precipitation is infrequent [Chin and Jacob, 1996]. The lifetime of sulfate in our simulation (3.9 days) is at the low end of the 3.6-7.5 days found in COSAM.

[22] Our annual average tropospheric ammonium burden $(0.32 \mathrm{Tg} \mathrm{N})$ is consistent with values from previous model

Table 1c. $\mathrm{NO}_{x}$ Emissions for $2001^{\mathrm{a}}$

\begin{tabular}{lcc}
\hline \multicolumn{1}{c}{ Source Type } & Globe & $\begin{array}{c}\text { Contiguous } \\
\text { United States }\end{array}$ \\
\hline Total & 43 & 7.4 \\
Anthropogenic source total & 27 & 6.8 \\
Fossil fuel use & 24 & 6.7 \\
Biofuel use & 2.2 & 0.02 \\
Fertilizer & 0.47 & 0.07 \\
Natural source total & 17 & 0.66 \\
Biomass burning & 6.5 & 0.05 \\
Natural soil & 5.3 & 0.36 \\
Lightning & 4.7 & 0.25 \\
\hline
\end{tabular}

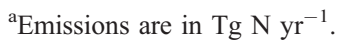




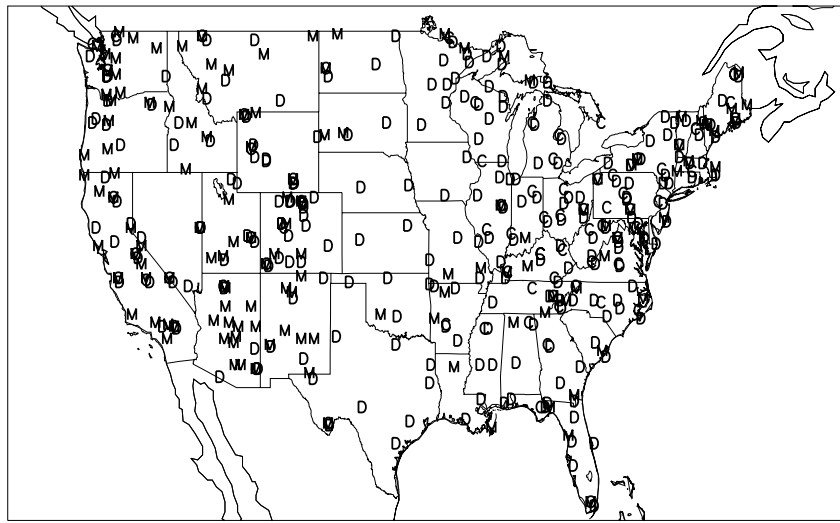

Figure 2. Sampling sites from the IMPROVE (M), CASTNET (C), and NADP (D) networks in 2001.

studies (0.30-0.33 Tg N) [Dentener and Crutzen, 1994; Adams et al., 1999], and the lifetime of ammonium is also similar (4.2-4.5 days). Our annual average tropospheric nitrate burden $(0.07 \mathrm{Tg} \mathrm{N})$ is within the range of $0.03-$ $0.09 \mathrm{Tg} \mathrm{N}$ found in the previous model study by Adams et al. [1999, 2001].

\section{Model Evaluation}

[23] We focus our model evaluation on surface networks of sulfate-nitrate-ammonium aerosol observations in the United States and Europe. We also use sulfate wet deposition data in the United States as a test of the sulfur budget and aircraft observations off the Asian Pacific Rim as a test of Asian export. Previous evaluation with sulfate observations at remote sites has been presented by Chin et al. [2000b] using the GOCART model which is similar to ours. Previous evaluations of GEOS-CHEM with aerosol radionuclides globally, and with carbonaceous aerosols in the United States, have been presented by Liu et al. [2001] and Park et al. [2003], respectively. Other GEOS-CHEM studies have evaluated the simulation of ozone and nitrogen oxides in the United States [Fiore et al., 2002, 2003a, 2003b; Li et al., 2004] and the trans-Pacific transport of Asian ozone and CO pollution [Jaeglé et al., 2003; Heald et al., 2003].

\subsection{United States}

[24] We use aerosol observations for the year 2001 at 141 IMPROVE and 79 CASTNET sites, and we use wet deposition data at 226 NADP sampling sites (Figure 2). The IMPROVE monitoring program was initiated in 1987 in national parks and other protected environments to identify the contributions of different aerosol components to visibility degradation [Malm et al., 1994]. The data for 2001 consist of 24-hour sulfate and nitrate concentrations measured every third day by particle-induced X-ray emission (PIXE) and ion chromatography (IC), respectively. There are no ammonium data. The CASTNET network of rural sites was initiated in 1990 to monitor regional air pollution [Lavery et al., 2002]. It provides weekly average concentrations of sulfate, nitrate, and ammonium measured by IC. The NADP network provides weekly chemical precipitation data [National Atmospheric Deposition
Program, 2002]. Sites are predominantly located in rural areas and away from point sources of pollution. Weekly precipitation samples are analyzed for sulfate using IC.

[25] Figure 3 compares simulated and observed annual mean sulfate concentrations at the 141 IMPROVE and 79 CASTNET sites for the year 2001, plotted on the $2^{\circ} \times 2.5^{\circ}$ model grid. Values are higher in the eastern than the western United States and are highest in the industrial midwest, reflecting the distribution of anthropogenic emissions. Figure 4 shows scatterplots of simulated versus observed annual and seasonal sulfate concentrations for the ensemble of (left) IMPROVE and (middle) CASTNET sites. The right column in Figure 4 compares simulated and observed sulfate precipitation data at NADP sites. The correlation between model and observations is high for the annual mean values $\left(R^{2}=0.91-0.94\right.$ for the concentration data and 0.75 for the deposition data) and also for the seasonal means $\left(R^{2}=0.79-0.90\right.$ for the concentration data and $0.58-0.74$ for the deposition data). Western sites in the scatterplots are represented with plus symbols and should be, in general, most representative of background conditions. The $R^{2}$ coefficients between model and observations for the subset of western sites alone are $0.35-0.39$ for the annual mean concentrations at the IMPROVE and CASTNET sites, lower than for the ensemble of U.S. sites, although this could largely reflect the weaker dynamic range. There is no

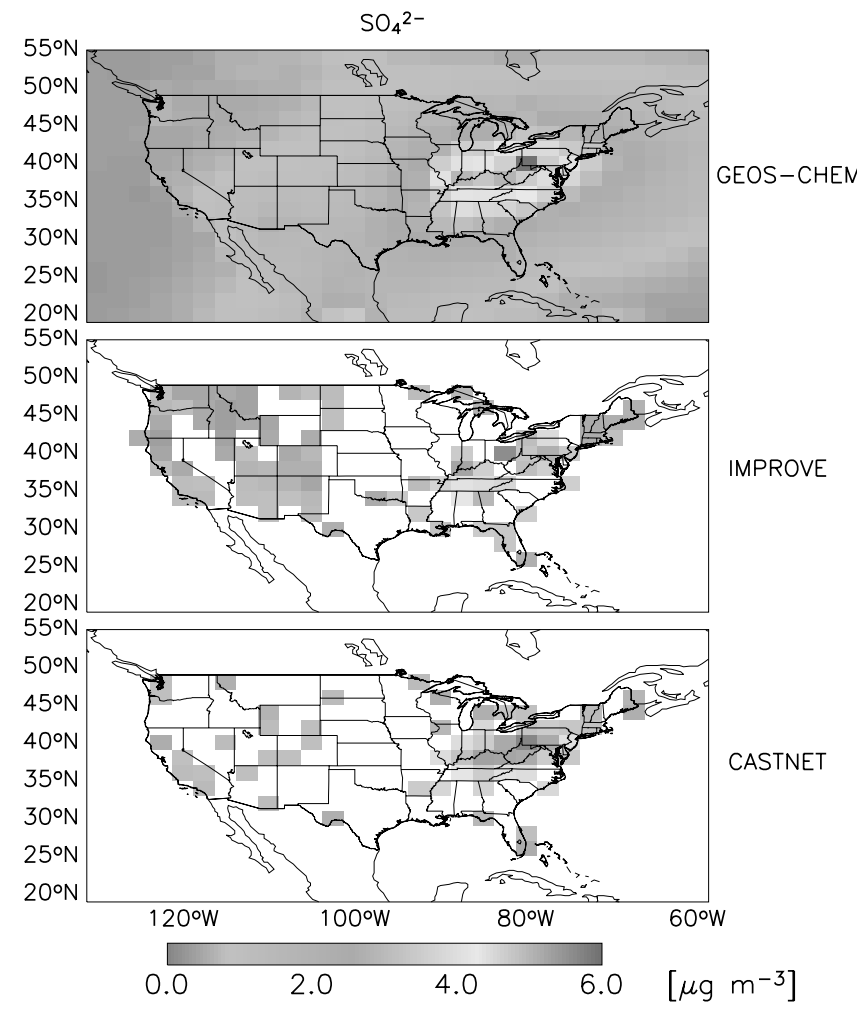

Figure 3. Annual mean concentrations of sulfate in surface air over the United States in 2001. (top) Results from the GEOS-CHEM model. (middle) Observations from the IMPROVE network averaged over the model $2^{\circ} \times 2.5^{\circ}$ grid. (bottom) Observations from the CASTNET network averaged over the model $2^{\circ} \times 2.5^{\circ}$ grid. See color version of this figure at back of this issue. 
IMPROVE
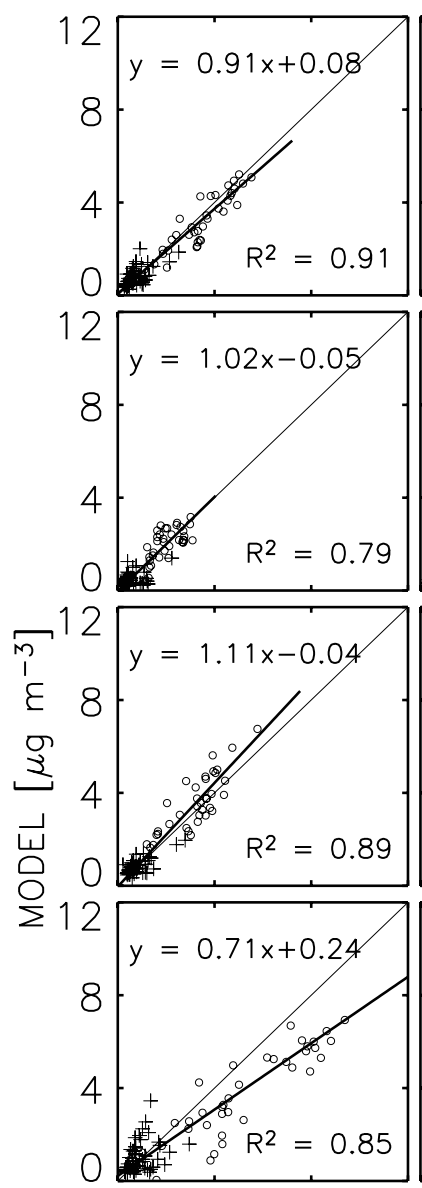

12

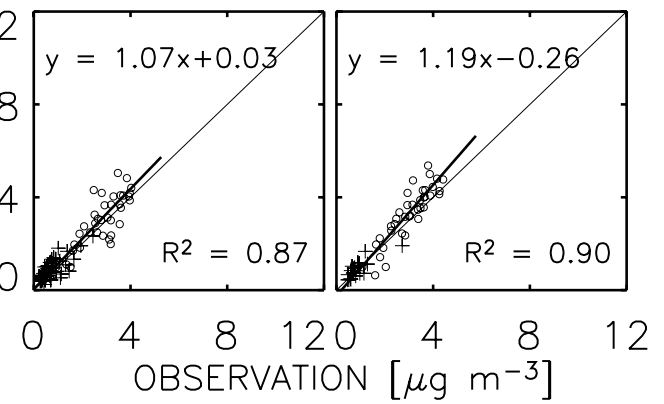

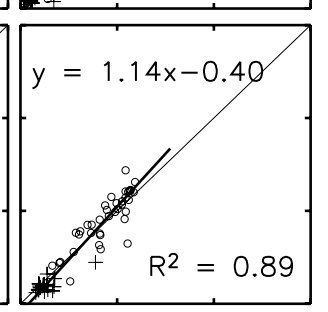

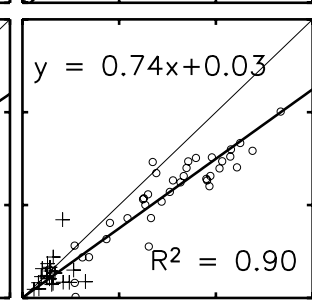

CASTNET
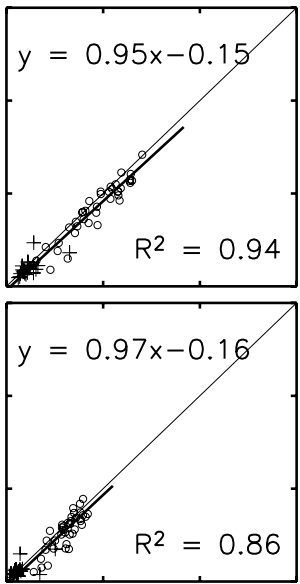

NADP

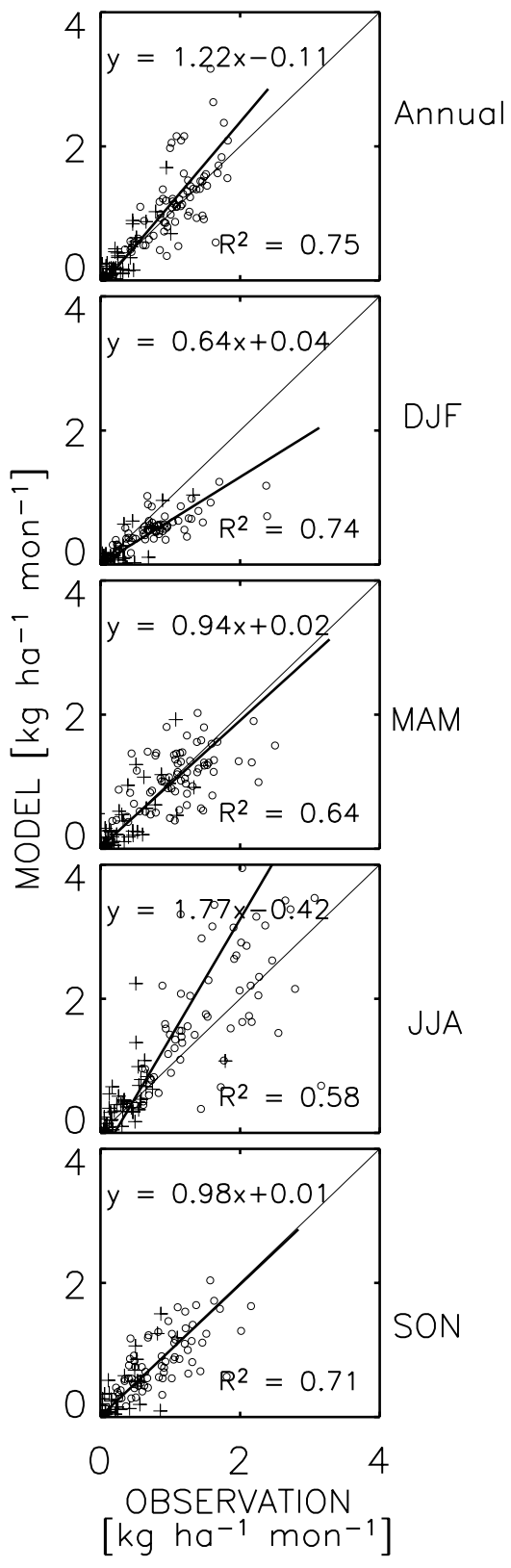

Figure 4. Scatterplot of simulated versus observed sulfate concentrations at the IMPROVE and CASTNET sites and sulfate deposition fluxes at NADP sites (Figure 2). Values are annual means (top panels) and seasonal means for 2001. Sites in the western (pluses) and eastern (circles) United States (separated at $95^{\circ} \mathrm{W}$ ) are shown. Reduced major axis regressions for the ensemble of the data (thick lines) are shown; regression equations and $R^{2}$ are shown inset. The $y=x$ relationship (thin lines) is shown. Abbreviations on right side are as follows: DJF, December, January, and February; MAM, March, April, and May; JJA, June, July, and August; and SON, September, October, and November.

significant bias in the simulation of concentrations at the cleanest western sites.

[26] Regression lines are computed here and elsewhere with the reduced major axis method, which minimizes the area of the right triangle formed by vertical and horizontal lines running from the observed point to the regression line. It is the most appropriate linear regression to characterize a relationship between two data sets with uncertainties [Hirsch and Gilroy, 1984]. Results in Figure 4 show no significant model bias in the simulation of annual mean concentrations (slope $=0.91-0.95$ ) except for a $30 \%$ low bias in summer (slope $=0.71-0.74$ ). Loss of $\mathrm{SO}_{2}$ in convective updrafts accounts for $\sim 50 \%$ of sulfate wet deposition in summer in the model and much less in other seasons. Our algorithm scavenges $\mathrm{SO}_{2}$ in convective updrafts as a titration reaction limited solely by the supply of $\mathrm{H}_{2} \mathrm{O}_{2}$ entrained in the updraft. However, kinetic limitations in the aqueous-phase reaction of $\mathrm{SO}_{2}$ with $\mathrm{H}_{2} \mathrm{O}_{2}$, as 


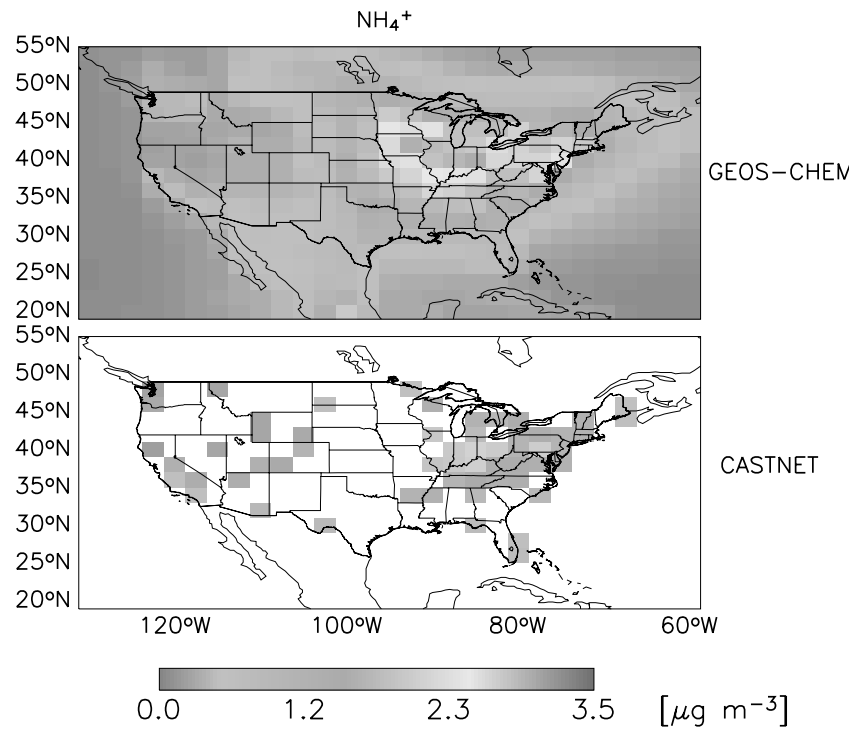

Figure 5. Annual mean concentrations of ammonium in surface air over the United States in 2001. (top) Results from the GEOS-CHEM model. (bottom) Observations from the CASTNET networks averaged over the model $2^{\circ} \times 2.5^{\circ}$ grid. (Ammonium is not measured at the IMPROVE sites.) See color version of this figure at back of this issue.

well as scavenging of $\mathrm{H}_{2} \mathrm{O}_{2}$, can greatly reduce the $\mathrm{SO}_{2}$ scavenging efficiency [Mari et al., 2000; Kreidenweis et al., 2003]. Accounting for these limitations might correct the model bias, but it was not attempted here.

[27] Figure 5 compares simulated and observed annual mean concentrations of ammonium at CASTNET sites. Observed concentrations are higher in the east than in the west and are highest in the midwest, reflecting agricultural operations. The model reproduces this spatial distribution but is too high in the midwest. Scatterplots of simulated versus observed annual and seasonal ammonium concentrations are shown in Figure 6 (left column) for the ensemble of sites. The model reproduces the variability of observed ammonium concentrations, both in an annual mean sense $\left(R^{2}=0.90\right)$ and in different seasons $\left(R^{2}=\right.$ $0.82-0.85$ ). It shows a $30 \%$ high bias in annual mean concentrations, which is mainly driven by the fall (slope $=$ 2.0). Comparison with results from the Gilliland et al. [2003] inverse model analysis suggests that our ammonia emissions are excessive in the fall (Figure 1). It appears that a simple exponential temperature dependence of emissions from livestock, as assumed here, does not adequately describe the seasonal variation of this dominant source. For the subset of western sites alone the model has a lower $R^{2}$ coefficient $(0.53)$ between the simulated and observed annual mean concentration than that for the ensemble of U.S. sites but no apparent high bias (slope $=1.02$ ).

[28] Figure 7 compares simulated and observed annual mean nitrate concentrations at the 141 IMPROVE and 79 CASTNET sites for 2001. The spatial distribution is similar to that of ammonium concentrations in both the observations and the model, reflecting the limitation of ammonium nitrate formation by the availability of ammonia as discussed further below. The model tends to be too high by a factor of 2 on an annual basis as shown by the scatterplots of Figure 6. Most of the bias is driven by summer and fall. Nitrate formation is determined by the availability of ammonia beyond that required for sulfate neutralization; we find in a sensitivity analysis that the summer high bias for nitrate can be explained in large part by the low bias of sulfate. High nitrate in fall is likely caused by excessive ammonia emissions. However, the factor of 2 high bias for the simulated annual mean nitrate concentration relative to the observation is not apparent for the subset of western sites alone (slope $=1.09-1.34$ ).

[29] Figure 8 shows the simulated gas ratio (GR) defined as

$$
\mathrm{GR}=\frac{\left[\mathrm{NH}_{3}^{T}\right]-2\left[\mathrm{SO}_{4}^{2-}\right]}{\left[\mathrm{HNO}_{3}^{T}\right]}
$$

where concentrations are in molar units, $\left[\mathrm{NH}_{3}^{T}\right]$ is the sum of gas-phase ammonia and aerosol-phase ammonium concentrations, $\left[\mathrm{HNO}_{3}^{T}\right]$ is the total inorganic nitrate concentration (sum of gas-phase nitric acid and aerosol nitrate), and $\left[\mathrm{SO}_{4}^{2-}\right]$ is the sulfate concentration. The value of GR diagnoses the limiting reactant (ammonia or nitric acid) for the formation of ammonium nitrate [Ansari and Pandis, 1998]. We find that ammonium nitrate formation in most of North America is generally limited by the supply of ammonia $(\mathrm{GR}<1)$. Exceptions are the upper Midwest and Mexico, where GR $>1$ indicates that nitrate formation is limited by the supply of nitric acid. Negative GR values, indicating an acidic sulfate aerosol, are mainly confined to the oceans. This neutralization of the aerosol is further illustrated in Figure 9, which compares the (top) simulated versus (bottom) observed acidity of aerosols at CASTNET sites for different seasons as the regression slopes of the $\left[\mathrm{NH}_{4}^{+}\right]$versus $\left(2\left[\mathrm{SO}_{4}^{2-}\right]+\left[\mathrm{NO}_{3}^{-}\right]\right)$scatterplots. The observations show an annual mean slope of 0.84 , i.e., within $16 \%$ of neutralization, and varying from 0.79 in summer to 0.93 in winter. The higher acidity in summer reflects the faster sulfate formation. The model is slightly less acidic than the observations on an annual mean basis (slope 0.90) but has the same seasonal trend ( 0.84 in summer, 0.98 in winter). The weaker apparent model acidity reflects at least in part the association of sulfate and nitrate in the observations with other alkaline cations (e.g., $\mathrm{Ca}^{2+}$ ) not included in the model.

\subsection{Europe}

[30] Figure 10 compares model results to annual and seasonal mean observations of sulfate, nitrate, and ammonium at 93 European EMEP sites in 1998. Sulfate in the model reproduces the variability in the observations $\left(R^{2}=\right.$ $0.60-0.78$ ) with no systematic bias (the regression slope for the annual mean data is 0.98 ). There is a slight underestimate in winter (slope $=0.84$ ), possibly caused by sea-salt sulfate included in the EMEP observations but not in the model [Chin et al., 2000b; Gong et al., 2002]. Simulated nitrate and ammonium compare less well with observations, with $40-60 \%$ overestimates of ammonium in summer and fall, likely due to excessive ammonia emission.

\subsection{Asia}

[31] We evaluate our simulation of Asian outflow by using sulfate observations from the TRACE-P aircraft 
CASTNET
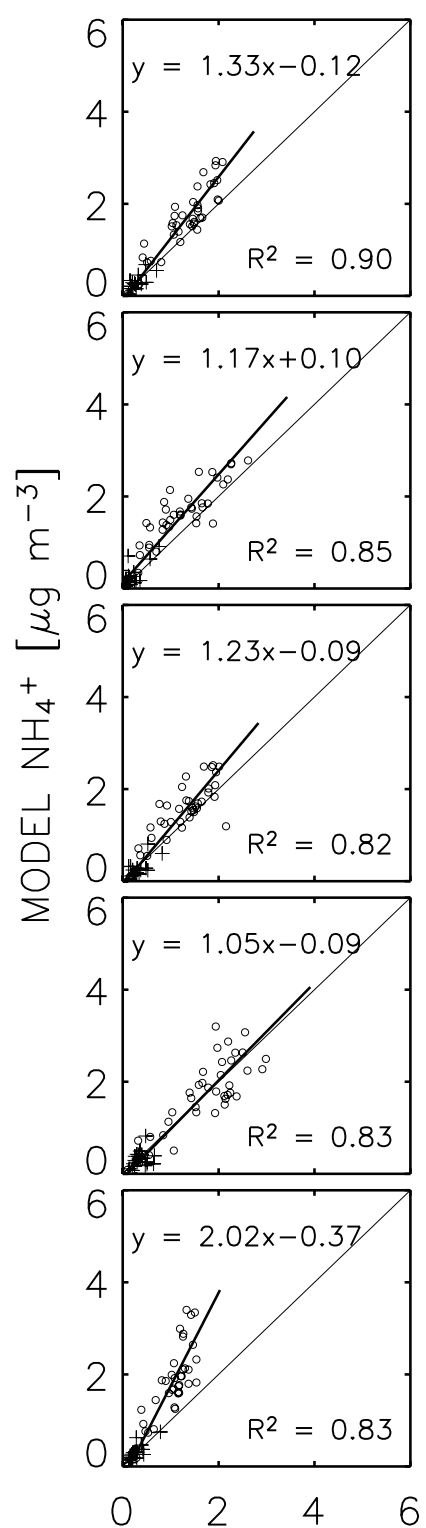

CASTNET
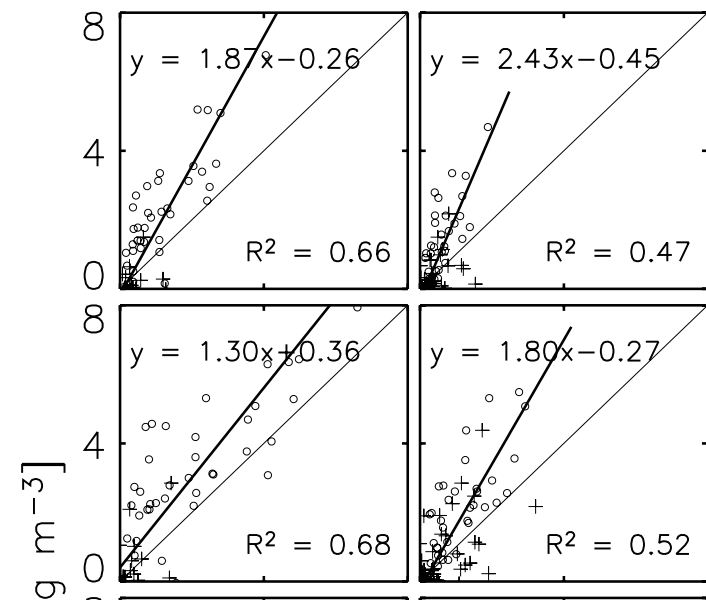

IMPROVE

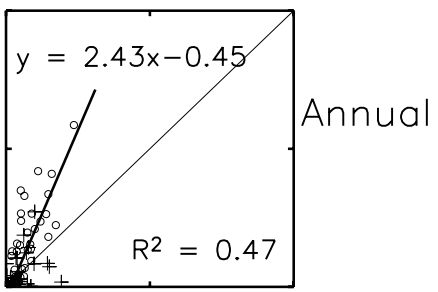

DJF
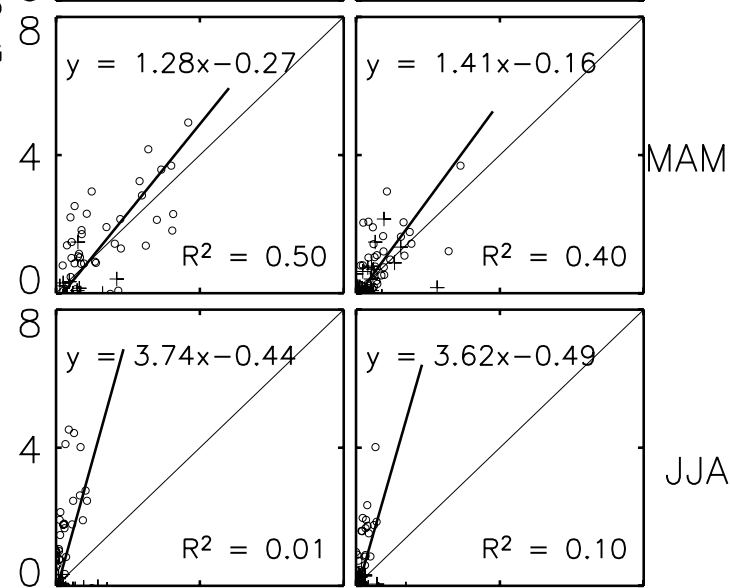

8

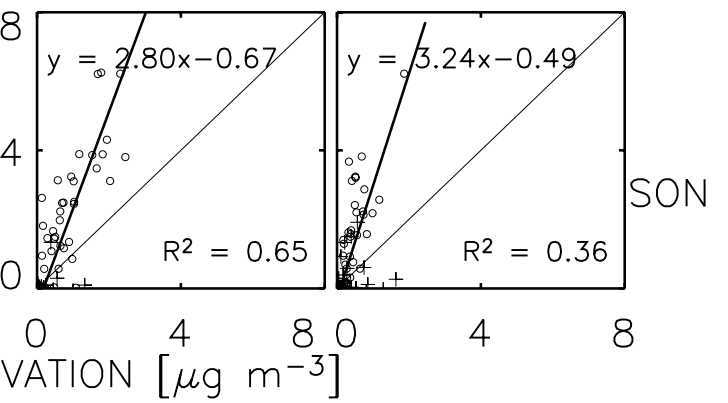

Figure 6. Scatterplot of simulated versus observed (left) ammonium concentrations at the CASTNET sites and nitrate concentrations at the (middle) CASTNET and (right) IMPROVE sites. Values are annual means (top panels) and seasonal means for 2001. Sites in the western (pluses) and eastern (circles) United States (separated at $95^{\circ} \mathrm{W}$ ) are shown. Reduced major axis regressions for the ensemble of the data (thick lines) are shown; regression equations and $R^{2}$ are shown inset. The $y=x$ relationship (thin lines) is shown.

mission conducted off the Asian Pacific Rim from bases in Hong Kong and Japan during February-April 2001 [Jacob et al., 2003]. Previous applications of GEOS-CHEM to simulation of TRACE-P observations for ozone, $\mathrm{CO}, \mathrm{CO}_{2}$, $\mathrm{CH}_{4}$, and nitriles indicate a good simulation of Asian outflow pathways [Liu et al., 2004; Heald et al., 2003; Palmer et al., 2003; Kiley et al., 2003; Suntharalingam et al., 2004; Xiao et al., 2004; Li et al., 2003]. Bulk aerosol measurements from the DC- 8 aircraft indicate that $40 \%$ of non-sea-salt sulfate (nss- $\mathrm{SO}_{4}^{2-}$ ) on average was incorporated in dust particles [Jordan et al., 2003]. Figure 11 compares mean vertical profiles of simulated and observed nss- $\mathrm{SO}_{4}^{2-}$ concentrations for the ensemble of DC-8 flights over the NW Pacific west of $177^{\circ} \mathrm{E}$ and at $30^{\circ}-45^{\circ} \mathrm{N}$ latitude [Liu et al., 2003]. Monthly mean concentrations in the model were sampled along the flight tracks. The observation shows strong outflow in the 0 - to $5-\mathrm{km}$ column. The model also shows an enhancement in that column but is lower than observations by up to a factor of 2 . Targeted sampling of Asian outflow in the observations [Jacob et al., 2003] could account for part of this discrepancy. In any case, the comparison argues that the model does not overestimate 


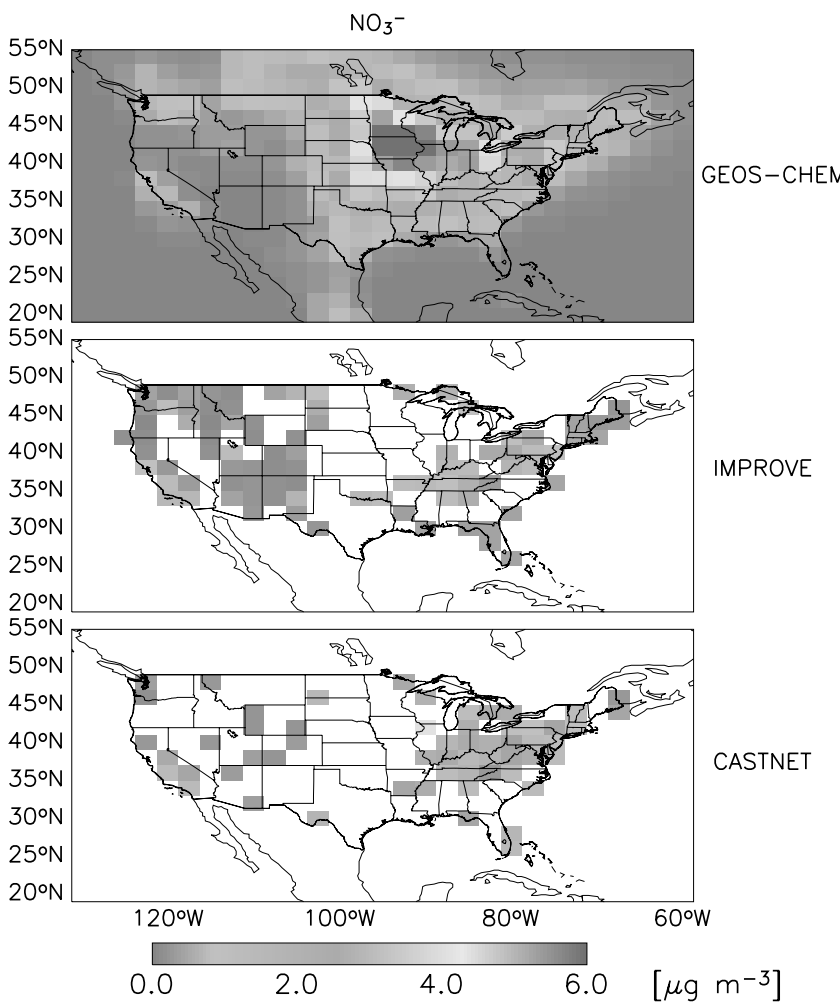

Figure 7. Same as in Figure 3 but for nitrate. See color version of this figure at back of this issue.

the outflow of sulfate from Asia. This is an important point for our section 4 discussion of trans-Pacific pollution influence.

\section{Background Aerosol in the United States: Transboundary Pollution Influence}

[32] We now apply our model simulations to quantify background sulfate-nitrate-ammonium aerosol concentrations in the United States and to separate the contributions to this background from natural sources and from transboundary pollution. We use for this purpose a sequence of four sensitivity simulations excluding anthropogenic emissions of both oxidant and aerosol precursors (1) globally, (2) in the United States, (3) in North America, and (4) in Asia. The results are summarized in Table 2 as annual averages for the western (west of $95^{\circ} \mathrm{W}$ ) and eastern United States. The U.S. EPA [2003, p. 2-2] Regional Haze Rule document recommends "default average natural concentrations of ammonium sulfate and ammonium nitrate" in these two regions to serve as 2064 endpoints for application of the rule. For the purpose of comparison we present our model results for sulfate and nitrate in Table 2 as those of the corresponding ammonium salts; in the model, almost all of the sulfate and nitrate are indeed associated with ammonium (Figure 9). Model results for the sum of natural and transboundary pollution contributions do not exactly add up to the independently calculated background concentrations because of chemical nonlinearities [Chin and Jacob, 1996; West et al., 1999].

[33] Our 2001 base simulation yields annual average concentrations of ammonium sulfate and ammonium nitrate

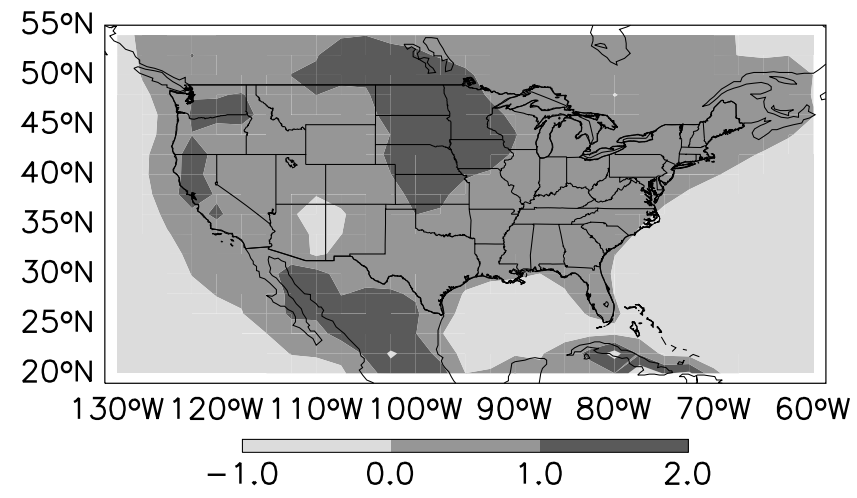

Figure 8. Simulated gas ratio (GR, equation (1)) defined as the available ammonia concentration beyond that required for sulfate neutralization, divided by the total inorganic nitrate concentration (gas plus aerosol) [Ansari and Pandis, 1998]. Values are computed from annual mean concentrations in surface air. Formation of ammonium nitrate aerosol is limited by the availability of nitric acid if GR $>1$ and by the availability of ammonia if $0<\mathrm{GR}<1$, and it is totally suppressed if GR $<0$.

of 1.52 and $1.53 \mu \mathrm{g} \mathrm{m}^{-3}$, respectively, for the western United States and 4.11 and $3.26 \mu \mathrm{g} \mathrm{m}^{-3}$, respectively, for the eastern United States. We use the sensitivity simulation with anthropogenic emissions shut off globally to estimate natural concentrations. They are $0.11 \mu \mathrm{g} \mathrm{m}^{-3}$ ammonium sulfate and $0.03 \mu \mathrm{g} \mathrm{m}^{-3}$ ammonium nitrate for both the western and eastern United States. Our estimate of natural concentrations for ammonium sulfate is consistent with the

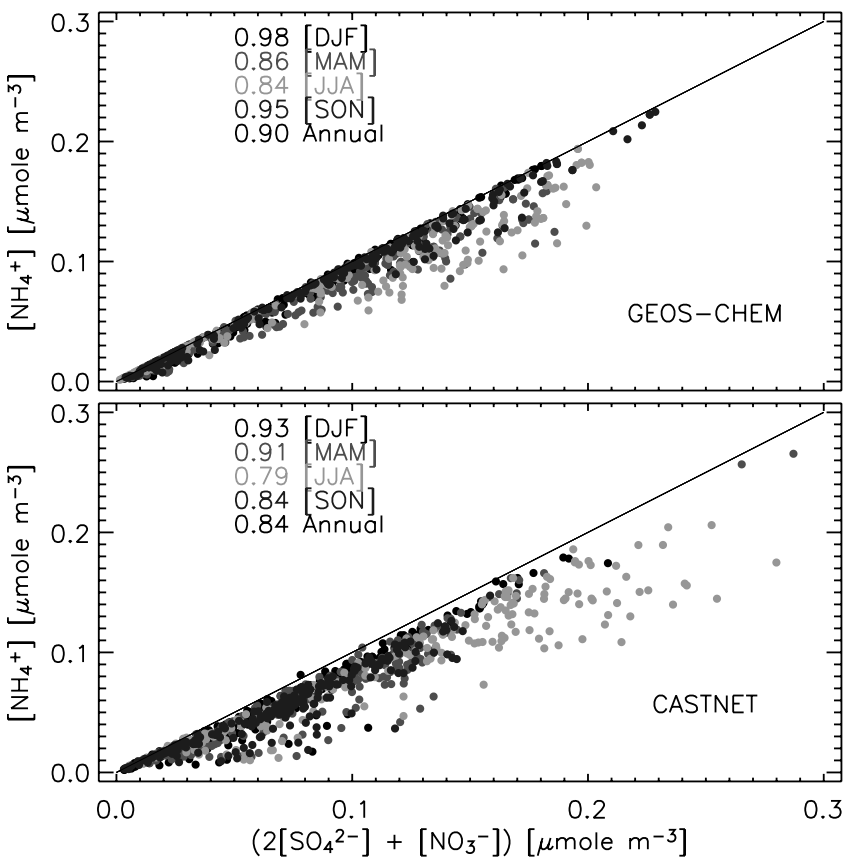

Figure 9. Scatterplot of seasonal mean $\left[\mathrm{NH}_{4}^{+}\right]$versus $\left(2\left[\mathrm{SO}_{4}^{2-}\right]+\left[\mathrm{NO}_{3}^{-}\right]\right)$at CASTNET sites in 2001 in the (top) GEOS-CHEM model and (bottom) observations. The reduced major axis regression slopes (given on the figure) indicate the degree of acid neutralization. See color version of this figure at back of this issue. 


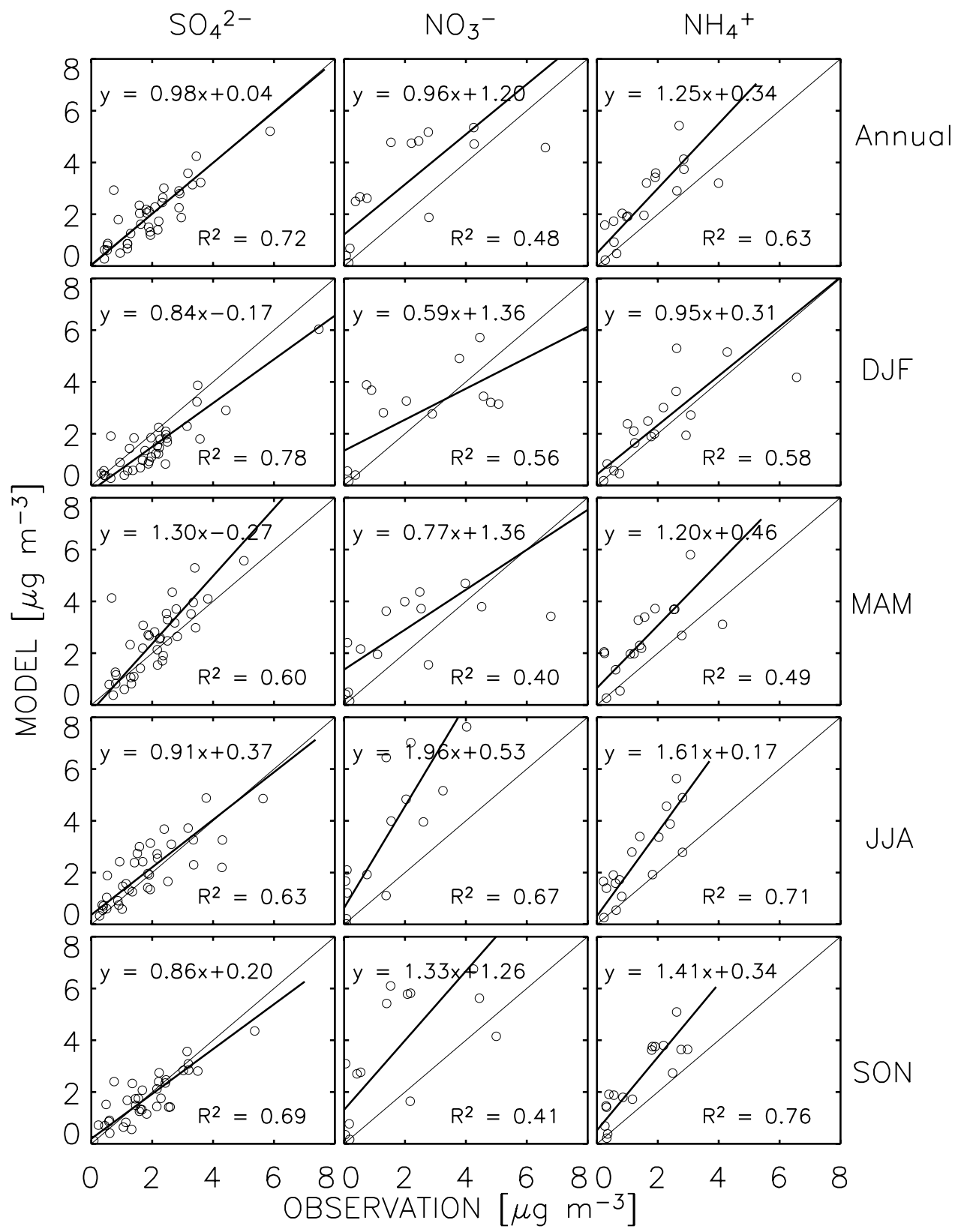

Figure 10. Scatterplot of simulated versus observed (left) sulfate, (middle) nitrate, and (right) ammonium concentrations at 93 European EMEP sites. Values are annual means (top panels) and seasonal means for 1998. Reduced major axis regressions for the ensemble of the data (thick lines) are shown; regression equations and $R^{2}$ are shown inset. The $y=x$ relationship (thin lines) is shown.

EPA default value $\left(0.12 \mu \mathrm{g} \mathrm{m}^{-3}\right)$ in the west but is factor of 2 lower than that $\left(0.23 \mu \mathrm{g} \mathrm{m}^{-3}\right)$ in the east. Oxidation of DMS is the major natural source of sulfate in the United States in the model. Our estimate of natural ammonium nitrate is 3 times lower than the EPA default value $\left(0.1 \mu \mathrm{g} \mathrm{m}^{-3}\right)$; it is not clear how that default value was obtained.

[34] Let us now examine the background concentrations from the sensitivity simulation including anthropogenic emissions only outside of the United States. The mean annual concentrations of background ammonium sulfate and nitrate in surface air over the United States are 0.43 and $0.27 \mu \mathrm{g} \mathrm{m}^{-3}$ for the West and 0.38 and $0.37 \mu \mathrm{g} \mathrm{m}^{-3}$ for the East, respectively. These values are several fold higher than the natural concentrations because of the influence from transboundary pollution. Background sulfate is slightly higher in the West than the East because of Asian pollution influence, as discussed further below, while background nitrate is higher in the East because of Canadian pollution influence.

[35] We thus find that transboundary pollution influence dominates over natural sources in contributing to sulfate and nitrate background concentrations in the United States. Transboundary transport of anthropogenic emissions from Canada and Mexico is most important for nitrate, but for sulfate, trans-Pacific transport of Asian pollution is of comparable importance (Table 2). Remarkably, we find that 


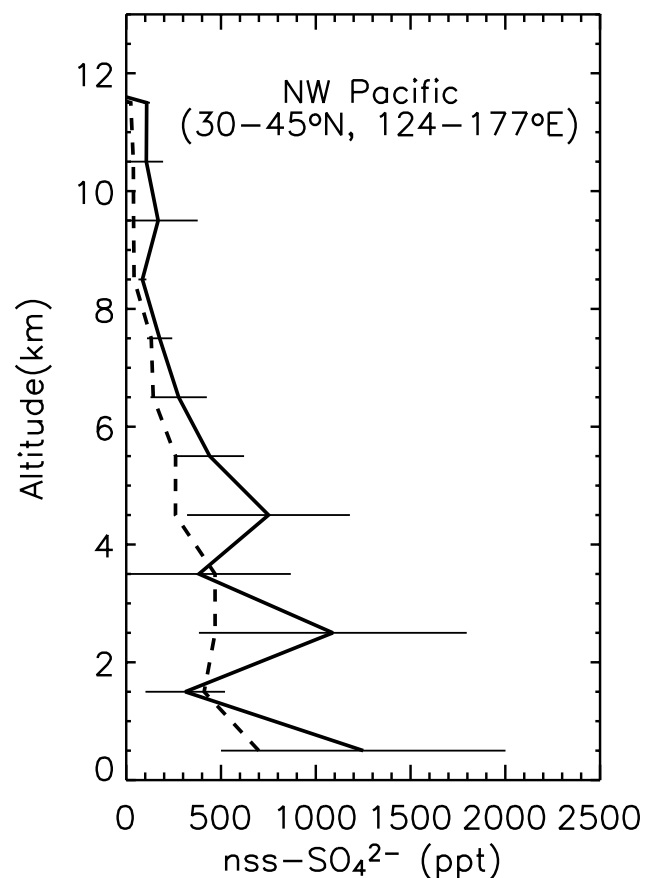

Figure 11. Simulated versus observed mean vertical profiles of non-sea-salt sulfate (nss- $\mathrm{SO}_{4}^{2-}$ ) concentrations over the NW Pacific from the TRACE-P aircraft mission in February-April 2001. The observations are binned vertically in 1-km intervals. Mean observed values from Jordan et al. [2003] for the ensemble of DC-8 flights north of $30^{\circ} \mathrm{N}$ $\left(30^{\circ}-45^{\circ} \mathrm{N}, 124^{\circ}-177^{\circ} \mathrm{E}\right)$ (solid line) with standard deviations (horizontal bars) are shown. Corresponding monthly mean model values along the flight tracks (dashed line) are shown.

this trans-Pacific pollution source accounts for $30 \%$ of the sulfate aerosol background in the United States.

[36] Figure 12a shows the global distribution of Asian pollution influence on sulfate-nitrate-ammonium aerosol concentrations in surface air, as determined by difference between the standard simulation and the sensitivity simula-

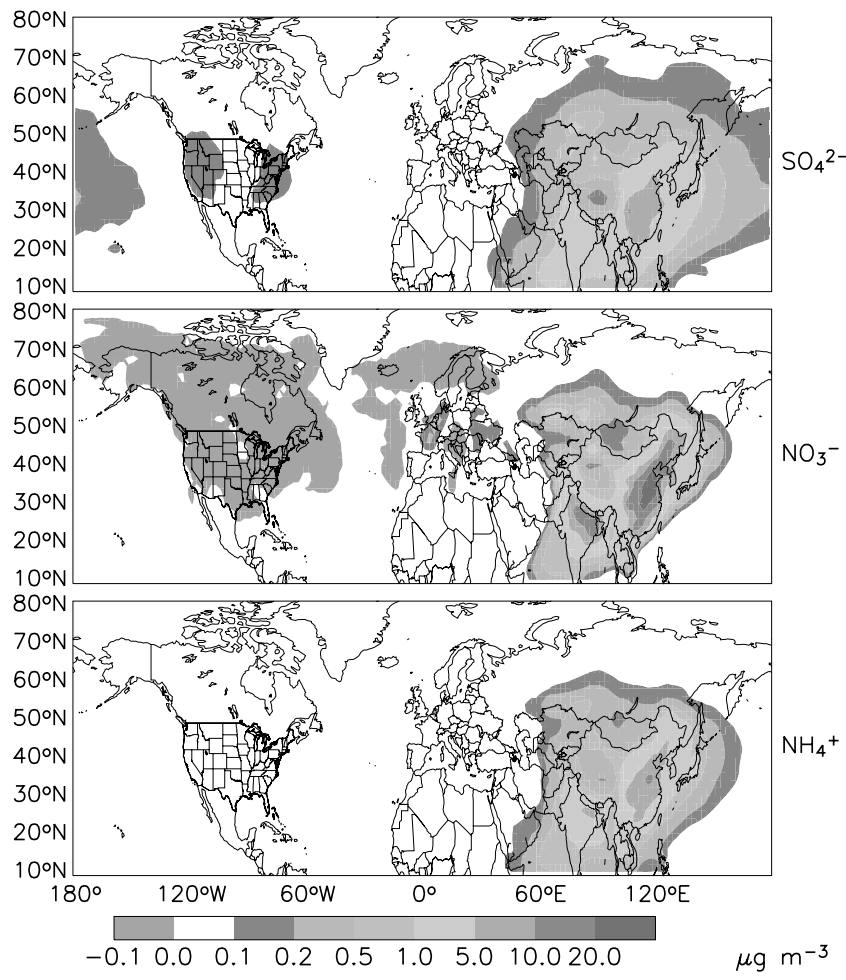

Figure 12a. Enhancements of sulfate-nitrate-ammonium aerosol concentrations in surface air due to anthropogenic emissions from Asia. Values are annual means for 2001, and they were obtained by difference between the standard model simulation and a sensitivity simulation with Asian anthropogenic sources shut off. See color version of this figure at back of this issue.

tion with anthropogenic Asian emissions shut off. TransPacific transport from Asia to the United States mostly involves lifting of Asian air to the free troposphere by wet processes (convection, warm conveyor belts), followed by rapid advection in the westerlies and subsidence over the United States, generally behind cold fronts. Ammonium aerosol as well as gas-phase ammonia are scavenged in this

Table 2. Background Aerosol Concentrations in the United States ${ }^{\mathrm{a}}$

\begin{tabular}{|c|c|c|c|c|c|c|c|c|}
\hline & \multicolumn{2}{|c|}{ Ammonium Sulfate } & \multicolumn{2}{|c|}{ Ammonium Nitrate } & \multicolumn{2}{|c|}{ Elemental Carbon } & \multicolumn{2}{|c|}{$\begin{array}{c}\text { Organic Carbon } \\
\text { Mass } \\
\end{array}$} \\
\hline & West & East & West & East & West & East & West & East \\
\hline Baseline (2001) & 1.52 & 4.11 & 1.53 & 3.26 & 0.27 & 0.66 & 1.77 & 3.07 \\
\hline Background & 0.43 & 0.38 & 0.27 & 0.37 & 0.08 & 0.06 & 1.3 & 1.22 \\
\hline Natural & 0.11 & 0.11 & 0.03 & 0.03 & 0.06 & 0.04 & 1.25 & 1.17 \\
\hline Transboundary pollution & 0.28 & 0.26 & 0.18 & 0.23 & 0.02 & 0.02 & 0.05 & 0.05 \\
\hline Canada and Mexico & 0.15 & 0.14 & 0.2 & 0.25 & 0.02 & 0.02 & 0.04 & 0.04 \\
\hline Asia & 0.13 & 0.12 & -0.02 & -0.02 & $<0.01$ & $<0.01$ & 0.01 & $<0.01$ \\
\hline EPA natural defaults ${ }^{\mathrm{b}}$ & 0.12 & 0.23 & 0.1 & 0.1 & 0.02 & 0.02 & 0.47 & 1.4 \\
\hline
\end{tabular}

${ }^{\mathrm{a}}$ Concentrations are in $\mu \mathrm{g} \mathrm{m}^{-3}$. Values are annual and spatial means from the standard 2001 simulation (baseline) and from the sensitivity simulations described in section 2.1. Partitioning between West and East is at $95^{\circ} \mathrm{W}$. Background and natural concentrations are obtained from the sensitivity simulations without U.S. and global anthropogenic emissions, respectively. Transboundary pollution influences from Canada and Mexico are determined by difference between two sensitivity simulations with anthropogenic emissions shut off in the United States versus in all of North America. Trans-Pacific pollution influences from Asia are determined by difference between the standard simulation and the sensitivity simulation with anthropogenic sources shut off in Asia. Results for elemental carbon (EC) and organic carbon mass (OMC) are from our previous work [Park et al., 2003] in a simulation using climatological emissions from wildfires.

${ }^{\mathrm{b}}$ U.S. EPA [2003, p. 2-2] recommended "default average natural concentrations" for estimating natural visibility conditions as 2064 endpoint in the application of the EPA Regional Haze Rule. 


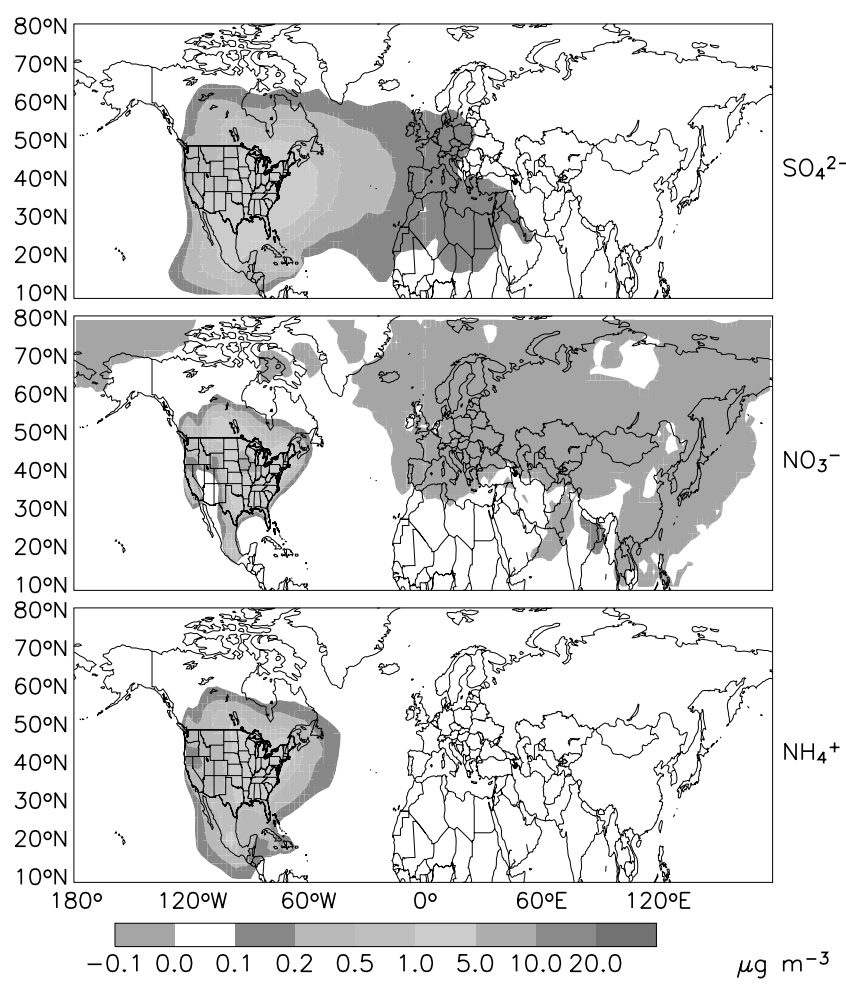

Figure 12b. Same as in Figure 12a but for anthropogenic emissions from North America. See color version of this figure at back of this issue.

wet lifting and we see therefore that trans-Pacific transport of ammonium is negligible. In contrast, significant transPacific transport of sulfate can occur as $\mathrm{SO}_{2}$ partly escapes scavenging during lifting [Mari et al., 2000; Koike et al., 2003; Tu et al., 2003]. Subsidence over the United States takes place mainly in the down-welling regions of the West and East, less in the up-welling region in the center of the country. Ammonium nitrate as we have seen is largely determined by difference between the total ammonium $\left[\mathrm{NH}_{3}^{T}\right]$ and the sulfate concentration, and the preferential export of sulfate relative to ammonium from Asia leads to a slight negative effect of Asian pollution on nitrate concentrations in the United States.

[37] It is of interest to compare the trans-Pacific influence of Asian pollution on North America to the transatlantic influence of North American pollution on Europe. Figure $12 \mathrm{~b}$ shows the latter as the difference between the standard simulation and the sensitivity simulation with anthropogenic emissions in North America shut off. We find a sulfate enhancement $>0.1 \mu \mathrm{g} \mathrm{m}^{-3}$ in surface air in Western Europe and northern Africa, comparable in magnitude to Asian pollution influence over North America. As in the case of Asian pollution, we find that export of ammonium from North American pollution is far less efficient than for sulfate, resulting in small negative influences on nitrate aerosol concentrations over Europe and Asia.

[38] We show also in Table 2 the natural and background concentrations of elemental carbon (EC) and organic carbon mass (OMC) from our previous work [Park et al., 2003]. In that work we derived optimized estimates of individual EC and $\mathrm{OMC}$ sources by fitting model results to observations from the IMPROVE sites. We concluded that the EPA default natural estimates were a factor of 3 too low in the West owing to underestimate of wildfire influences. Our values for the East were more consistent with EPA. In contrast to sulfate and nitrate, transboundary transport of anthropogenic carbonaceous aerosols is insignificant relative to the large natural influences from wildfires and vegetation. We further find that trans-Pacific transport of carbonaceous aerosols from Asian pollution is less efficient than for sulfate because of scavenging in the wet lifting processes involved in Asian outflow. The excess of $\mathrm{SO}_{2}$ over $\mathrm{H}_{2} \mathrm{O}_{2}$ in the Asian outflow allows part of the sulfur to escape scavenging [Koike et al., 2003; Tu et al., 2003]. This result is consistent with Jaffe et al. [2003], who found a larger increase in sulfate concentrations relative to carbonaceous aerosol at three IMPROVE sites in the western United States during a trans-Pacific transport event of Asian pollution.

\section{Policy Implications: Regional Haze Rule}

[39] The U.S. EPA [2003] Regional Haze Rule requires states to develop plans for achieving natural visibility conditions in national parks and other wilderness areas by 2064. Visibility degradation is measured by the deciview (dv) index

$$
\mathrm{dv}=10 \ln \left(b_{\mathrm{ext}} / 10\right),
$$

where $b_{\text {ext }}$ is atmospheric light extinction in units of inverse megameters $\left(\mathrm{Mm}^{-1}=10^{-6} \mathrm{~m}^{-1}\right)$. In the phase 1 implementation of the Regional Haze Rule, states have to show how they will decrease anthropogenic emissions over the 2004-2018 period in order to achieve a linear trajectory of decreasing deciviews toward the natural visibility endpoint of 2064. A linear decrease in deciviews implies an exponential decrease in aerosol extinction; as a result, and as we will see, the definition of the 2064 endpoint has important implications for determining the level of emission controls required during the 2004-2018 phase 1 implementation.

[40] The U.S. EPA [2003] Regional Haze Rule document recommends a simple formula to estimate aerosol extinction by using dry mass concentrations of individual aerosol components (ammonium sulfate, ammonium nitrate, OMC, EC, soil dust, and coarse mass (CM)), as follows:

$$
\begin{aligned}
b_{\text {ext }}= & 3 f(\mathrm{RH})\left[\left(\mathrm{NH}_{4}\right)_{2} \mathrm{SO}_{4}\right]+3 f(\mathrm{RH})\left[\mathrm{NH}_{4} \mathrm{NO}_{3}\right]+4[\mathrm{OMC}] \\
& +10[\mathrm{EC}]+[\mathrm{soil}]+0.6[\mathrm{CM}]+10
\end{aligned}
$$

where $b_{\text {ext }}$ is in units of $\mathrm{Mm}^{-1}$, aerosol concentrations are in units of $\mu \mathrm{g} \mathrm{m}^{-3}$, and $f(\mathrm{RH})$ is a correction factor for hygroscopic growth as a function of relative humidity $(\mathrm{RH})$. The constant of $10 \mathrm{Mm}^{-1}$ describes the scattering by air molecules and is such that an aerosol-free atmosphere would have a deciview index of zero. The term "soil" in equation (3) is the fine component of soil dust (diameter $<2.5 \mu \mathrm{m})$ and "coarse mass" is the total mass of particles with diameter $>2.5 \mu \mathrm{m}$, mostly contributed by dust and sea 
Table 3. Visibility Degradation in the United States ${ }^{\mathrm{a}}$

\begin{tabular}{lcc}
\hline & West & East \\
\hline Baseline (2001) $_{\text {Background }^{\mathrm{b}}}$ & 14 & 23 \\
Natural & 8.1 & 9.0 \\
This work & 6.3 & 6.2 \\
EPA default & 4.6 & 7.5 \\
\hline
\end{tabular}

${ }^{a}$ Visibility degradation is in deciviews (equation (2)) and calculated from mean annual aerosol extinction as given by equation (3). Aerosol concentrations for use in equation (3) are from Table 2, with, in addition, EPA default natural values for soil $\left(0.5 \mu \mathrm{g} \mathrm{m}^{-3}\right)$ and coarse mass $(\mathrm{CM}, 3.0 \mu \mathrm{g}$ $\mathrm{m}^{-3}$ ). Values of $f(\mathrm{RH})$ in equation (3) are 2 in the west and 3 in the east.

${ }^{b}$ This includes contributions to visibility degradation from both natural and transboundary pollution sources.

salt. Recommended values of $f(\mathrm{RH})$ for individual wilderness areas are given in the Regional Haze Rule document [U.S. EPA, 2003]. In what follows, we use typical $f(\mathrm{RH})$ values of 2 and 3 for the West and East, respectively.

[41] Applying equation (3) to aerosol concentrations given in Table 2, and assuming EPA natural default values for fine soil dust $\left(0.5 \mu \mathrm{g} \mathrm{m}^{-3}\right)$ and coarse mass $\left(3.0 \mu \mathrm{g} \mathrm{m}^{-3}\right)$, we compute deciview index values for baseline (presentday) conditions and for different definitions of the 2064 natural or background visibility endpoint. We use the results
(Table 3) to estimate the implications of our results for phase 1 (2004-2018) implementation of the Regional Haze Rule. Under the EPA Regional Haze Rule, the linear improvement in visibility is to be applied to the $20 \%$ most impaired visibility days and at specific locations. Here we use visibility calculated from annual mean aerosol extinctions averaged over the western and eastern United States. Nevertheless, the results serve to illustrate the sensitivity of the required 2004-2018 emission controls to the choice of 2064 endpoint.

[42] Table 3 gives a baseline (current) visibility degradation of 14 and $23 \mathrm{dv}$ for the western and the eastern United States, respectively. The natural visibility degradation is 6.3 and $6.2 \mathrm{dv}$, respectively. Organic aerosols are the dominant contributors to natural visibility degradation. Our estimate for natural visibility degradation as expressed in deciviews is $37 \%$ higher in the West and $17 \%$ lower in the East than the values computed using the natural default aerosol concentrations recommended by EPA (4.6 and $7.5 \mathrm{dv})$. We have previously argued in Park et al. [2003] that the EPA natural default concentrations underestimate the influence of wildfires in the West.

[43] Figure 13 shows the trajectories of linear visibility improvement toward a 2064 endpoint of natural visibility defined either from our results (dashed line) or from the

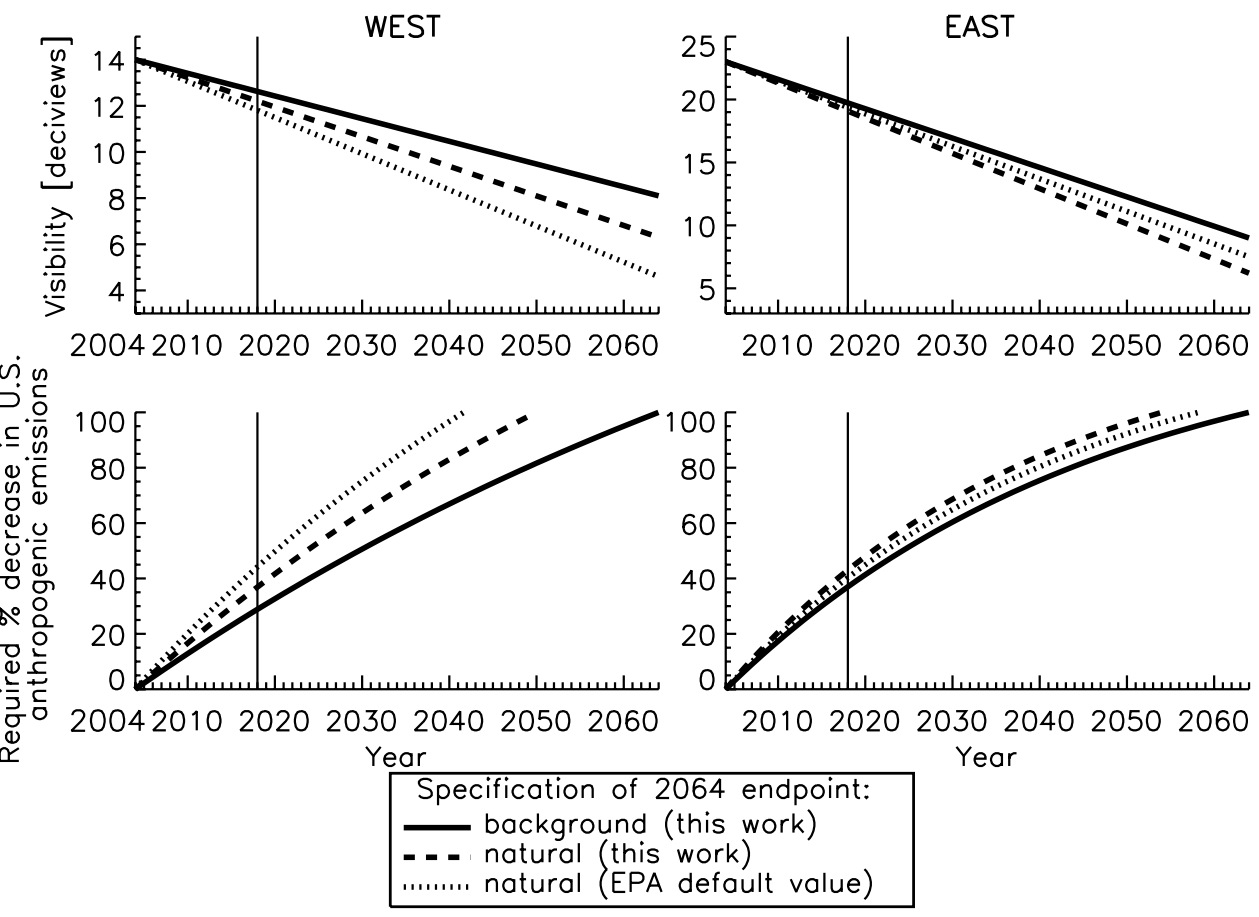

Figure 13. Illustrative example of (top) required visibility improvements and (bottom) domestic emission reductions over the 2004-2064 period for the western and the eastern United States (separated at $95^{\circ} \mathrm{W}$ ) under the U.S. EPA [2003] Regional Haze Rule. The visibility endpoints are as given in Table 3. The required percentage decrease in U.S. anthropogenic emissions corresponding to a given visibility improvement is computed by assuming a linear correspondence between aerosol extinction and emissions. Results are shown for different choices for the 2064 endpoint: (1) EPA natural default visibility (dotted lines), (2) our estimate of natural visibility (dashed lines), and (3) our estimate of background visibility (solid lines). Background includes contributions from both natural and transbounary pollution sources. Year 2018 (vertical line) is the target date for phase 1 implementation of the Regional Haze Rule. 
EPA defaults (dotted line). Following these trajectories, we find that visibility degradation during the 2004-2018 phase 1 implementation of the Regional Haze Rule should be reduced by 1.8 (West) and $3.9 \mathrm{dv}$ (East) if our estimate of the 2064 natural visibility endpoint is used and by 2.2 (West) and $3.6 \mathrm{dv}$ (East) if the EPA default endpoint is used. The corresponding reductions in light extinction are 6.7 $\mathrm{Mm}^{-1}$ (West) and $32.2 \mathrm{Mm}^{-1}$ (East) if our estimate of the 2064 natural visibility endpoint is used and $8.1 \mathrm{Mm}^{-1}$ (West) and $30.1 \mathrm{Mm}^{-1}$ (East) if the EPA default endpoint is used.

[44] Let us now estimate the required percentage reductions in U.S. anthropogenic emissions needed to achieve such improvements in light extinction. We assume a linear correspondence between aerosol extinction, aerosol concentrations, and emissions. The current aerosol extinction from U.S. anthropogenic emissions can be calculated from the data in Table 2 by subtracting the background from the baseline aerosol concentrations and applying equation (3). We obtain values of $18.1 \mathrm{Mm}^{-1}$ in the West and $73 \mathrm{Mm}^{-1}$ in the East. The resulting percentage decreases of U.S. anthropogenic emissions over 2004-2018 are shown in Figure 13 . They are $37 \%$ and $44 \%$ for the western and eastern United States, respectively, using our natural visibility endpoint, and $44 \%$ and $41 \%$, respectively, using the EPA natural visibility endpoint.

[45] These differences are significant, but looking beyond the 2018 horizon exposes a more fundamental problem with the Regional Haze Rule. Continued linear decrease toward a 2064 natural visibility endpoint would require total shutdown of U.S. anthropogenic emissions by 2041-2049 (West) or 2053-2058 (East), as shown in Figure 13. Because of transboundary pollution (assumed here to be unchanged in the future), natural visibility cannot be achieved even with total suppression of U.S. anthropogenic emissions. It will be therefore necessary to either impose emission controls on an international level or amend the 2064 endpoint to allow for uncontrollable transboundary pollution influences. Such an amendment should define the 2064 endpoint as a background rather than natural visibility. One would then have to make estimates of future trends in foreign emissions.

[46] However, amendment of the Regional Haze Rule to target a background visibility endpoint has major implications for phase 1 (2004-2018) emission controls in the West. Using the background deciview values in Table 3 as 2064 endpoint, the required 2004-2018 decrease in visibility degradation is 1.4 (West) and $3.3 \mathrm{dv}$ (East). The corresponding percentage decrease of U.S. anthropogenic emissions in the West is $29 \%$, much lower than $37 \%$ if a natural visibility endpoint from our results is used or $44 \%$ if the natural visibility endpoint from the EPA defaults is used.

\section{Conclusions}

[47] We used a global 3-D coupled oxidant-aerosol model (GEOS-CHEM) to quantify natural and transboundary pollution influences on sulfate-nitrate-ammonium aerosol concentrations in the United States. The U.S. EPA Regional Haze Rule requires immediate action to improve visibility in U.S. national parks and other wilderness areas along a linear trajectory toward an endpoint of natural visibility conditions by 2064 . We need to better quantify the natural aerosol concentrations defining this natural visibility and to determine if transboundary transport of pollution not amenable to domestic emission controls elevates background aerosol concentrations in the United States significantly above the natural values. If they do, then the Regional Haze Rule must either involve international emission controls or be amended to an endpoint of background as opposed to natural visibility. Background is defined here following U.S. EPA (manuscript in preparation, 2003) as the aerosol concentrations that would be present in the absence of U.S. anthropogenic emissions, but allowing for contributions from transboundary pollution.

[48] We conducted full-year simulations for 1998 and 2001. Results were evaluated with observations from surface networks in the United States and Europe (IMPROVE, CASTNET, NADP, EMEP) and with Asian outflow observations from the NASA TRACE-P aircraft mission over the northwest Pacific. The model reproduces well the spatial pattern and variability of sulfate observations in the United States and Europe across all seasons, with no systematic biases. Comparison with the TRACE-P observations indicates that Asian outflow of sulfate is, if anything, underestimated. Nitrate and ammonium aerosol concentrations in the model are highly correlated with observations but are too high in summer and fall, a problem that we attribute to seasonal overestimate of ammonia emissions [Gilliland et al., 2003]. We find that the availability of ammonia limits the formation of ammonium nitrate in most of North America. The aerosol is typically $80-100 \%$ neutralized, both in the model and in the observations, with maximum acidity in summer.

[49] We used a sequence of sensitivity simulations to quantify background sulfate-nitrate-ammonium aerosol concentrations in the United States and to separate the contributions to this background from natural sources and from transboundary pollution. Our 2001 base simulation yields annual average concentrations of ammonium sulfate and ammonium nitrate of 1.52 and $1.53 \mu \mathrm{g} \mathrm{m}^{-3}$, respectively, for the western United States and 4.11 and $3.26 \mu \mathrm{g} \mathrm{m}^{-3}$, respectively, for the eastern United States. Our best estimates of mean annual natural concentrations are $0.11 \mu \mathrm{g}$ $\mathrm{m}^{-3}$ ammonium sulfate and $0.03 \mu \mathrm{g} \mathrm{m}^{-3}$ ammonium nitrate for both the western and eastern United States. Our values are consistent with or lower than the default values recommended by EPA for natural visibility calculations in the context of the Regional Haze Rule.

[50] Our best estimates of background concentrations for ammonium sulfate and ammonium nitrate are 0.43 and $0.27 \mu \mathrm{g} \mathrm{m}^{-3}$ for the West and 0.38 and $0.37 \mu \mathrm{g} \mathrm{m}^{-3}$ for the East. These values are considerably higher than the natural concentrations, pointing to the dominance of transboundary pollution in defining the background. TransPacific transport of Asian pollution is of comparable importance to transport from Canada and Mexico in contributing to the background sulfate enhancement over the United States. A significant enhancement of sulfate relative to other aerosols in the Asian outflow can occur as $\mathrm{SO}_{2}$ partly escapes scavenging during wet lifting processes. In the case of ammonium nitrate, the transboundary pollution enhancement is mostly from Canada, and trans-Pacific Asian pollu- 
tion actually causes a slight depression $\left(<0.1 \mu \mathrm{g} \mathrm{m}^{-3}\right)$ owing to the added sulfate.

[51] We assessed the implications of our results for implementation of the Regional Haze Rule. For this purpose we used our model to define the linear trend of visibility from present (2004) to natural or background (2064) conditions. We found that transboundary pollution prevents natural visibility from being achieved even with total suppression of U.S. anthropogenic emissions, implying the need for either international emission controls or for amendment of the 2064 endpoint to allow for uncontrollable transboundary pollution influences. The latter would require some estimates of future trends in transboundary pollution influences, but these have large uncertainties. Projections by IPCC [2001] for 2060 anthropogenic sulfur emissions from Asia range from 30 to $160 \%$ of present-day levels depending on the socioeconomic scenario. Consideration of a background rather than natural visibility 2064 endpoint would have immediate implications for phase 1 implementation (20042018) of the Regional Haze Rule. It would imply, at least in the West, a significantly slower schedule of U.S. anthropogenic emission reductions.

[52] Our results are only a first attempt to quantify natural and transboundary pollution influences in the United States using a global 3-D model analysis. In future work we plan to examine in more detail the observational constraints on aerosol background concentrations in the United States, including site-by-site analysis and frequency distributions of aerosol concentrations. Specification of natural and background aerosol concentrations for regulatory purposes will require formal uncertainty bounds to be placed on model estimates, and again this will require more extensive evaluation with observations as well as higher-resolution simulations with a nested regional model.

[53] Acknowledgments. This work was supported by the Electric Power Research Institute (EPRI) and by the EPA Intercontinental Transport and Climatic Effects of Air Pollutants (ICAP) program. Development of the GEOS-CHEM model is supported by the Atmospheric Chemistry Modeling and Analysis Program (ACMAP) of the National Aeronautics and Space Administration (NASA).

\section{References}

Adams, P. J., J. H. Seinfeld, and D. M. Koch (1999), Global concentrations of tropospheric sulfate, nitrate, and ammonium aerosol simulated in a general circulation model, J. Geophys. Res., 104(D11), 13,791-13,823.

Adams, P., J. Seinfeld, D. Koch, L. Mickley, and D. Jacob (2001), General circulation model assessment of direct radiative forcing by the sulfatenitrate-ammonium-water inorganic aerosol system, J. Geophys. Res., 106(D1), 1097-1112.

Andreae, M. O., and P. Merlet (2001), Emission of trace gases and aerosols from biomass burning, Global Biogeochem. Cycles, 15(4), 955-966.

Andres, R. J., and A. D. Kasgnoc (1998), A time-averaged inventory of subaerial volcanic sulfur emissions, J. Geophys. Res., 103(D19), 25,25125,261 .

Aneja, V. P., J. P. Chauhan, and J. T. Walker (2000), Characterization of atmospheric ammonia emissions from swine waste storage and treatment lagoons, J. Geophys. Res., 105(D9), 11,535-11,545.

Ansari, A. S., and S. N. Pandis (1998), Response of inorganic PM to precursor concentrations, Environ. Sci. Technol., 32, 2706-2714.

Barrie, L. A., et al. (2001), A comparison of large-scale atmospheric sulphate aerosol models (COSAM): Overview and highlights, Tellus, Ser. B, 53(5), 615-645.

Benkovitz, C. M., M. T. Scholtz, J. Pacyna, L. Tarrason, J. Dignon, E. C. Voldner, P. A. Spiro, J. A. Logan, and T. E. Graedel (1996), Global gridded inventories of anthropogenic emissions of sulfur and nitrogen, J. Geophys. Res., 101(D22), 29,239-29,253.
Berntsen, T. K., S. Karlsdóttir, and D. A. Jaffe (1999), Influence of Asian emissions on the composition of air reaching the northwestern United States, Geophys. Res. Lett., 26(14), 2171-2174.

Bertschi, I. T., D. A. Jaffe, L. Jaeglé, H. U. Price, and J. B. Dennison (2004), PHOBEA/ITCT 2002 Airborne observations of trans-Pacific transport of ozone, CO, VOCs, and aerosols to the northeast Pacific: Impacts of Asian anthropogenic and Siberian boreal fire emissions, J. Geophys. Res., 109, D23S12, doi:10.1029/2003JD004328.

Bey, I., D. J. Jacob, R. M. Yantosca, J. A. Logan, B. Field, A. M. Fiore, Q. Li, H. Liu, L. J. Mickley, and M. Schultz (2001a), Global modeling of tropospheric chemistry with assimilated meteorology: Model description and evaluation, J. Geophys. Res., 106(D19), 23,07323,096.

Bey, I., D. J. Jacob, J. A. Logan, and R. M. Yantosca (2001b), Asian chemical outflow to the Pacific in spring: Origins, pathways, and budgets, J. Geophys. Res., 106(D19), 23,097-23,113.

Binkowski, F. S., and S. J. Roselle (2003), Models-3 Community Multiscale Air Quality (CMAQ) model aerosol component: 1. Model description, J. Geophys. Res., 108(D6), 4183, doi:10.1029/2001JD001409.

Bouwman, A. F., D. S. Lee, W. A. H. Asman, F. J. Dentener, K. W. VanderHoek, and J. G. J. Olivier (1997), A global high-resolution emission inventory for ammonia, Global Biogeochem. Cycles, 11(4), $561-587$.

Chatfield, R. B., and P. J. Crutzen (1990), Are there interactions of iodine and sulfur species in marine air photochemistry?, J. Geophys. Res., 95(D13), 22,319-22,341.

Chin, M., and D. J. Jacob (1996), Anthropogenic and natural contributions to tropospheric sulfate: A global model analysis, J. Geophys. Res., 101(D13), 18,691-18,699.

Chin, M., D. J. Jacob, G. M. Gardner, M. S. Foreman-Fowler, P. A. Spiro, and D. L. Savoie (1996), A global three-dimensional model of tropospheric sulfate, J. Geophys. Res., 101(D13), 18,667-18,690.

Chin, M., R. B. Rood, S.-J. Lin, J.-F. Müller, and A. M. Thompson (2000a), Atmospheric sulfur cycle simulated in the global model GOCART: Model description and global properties, J. Geophys. Res., 105(D20), 24,671$24,687$.

Chin, M., D. L. Savoie, B. J. Huebert, A. R. Bandy, D. C. Thornton, T. S. Bates, P. K. Quinn, E. S. Saltzman, and W. J. De Bruyn (2000b), Atmospheric sulfur cycle simulated in the global model GOCART: Comparison with field observations and regional budgets, J. Geophys. Res., 105(D20), 24,689-24,712.

DeMore, W. B., S. P. Sander, D. M. Golden, R. F. Hampson, M. J. Kurylo, C. J. Howard, A. R. Ravishankara, C. E. Kolb, and M. J. Molina (1997), Chemical kinetics and photochemical data for use in stratospheric modeling, JPL Publ., 97-4, 1-278.

Dentener, F. J., and P. J. Crutzen (1994), A 3-dimensional model of the global ammonia cycle, J. Atmos. Chem., 19(4), 331-369.

Duncan, B. N., R. V. Martin, A. C. Staudt, R. Yevich, and J. A. Logan (2003), Interannual and seasonal variability of biomass burning emissions constrained by satellite observations, J. Geophys. Res., 108(D2), 4100, doi:10.1029/2002JD002378

Fiore, A. M., D. J. Jacob, I. Bey, R. M. Yantosca, B. D. Field, A. C. Fusco, and J. G. Wilkinson (2002), Background ozone over the United States in summer: Origin, trend, and contribution to pollution episodes, J. Geophys. Res., 107(D15), 4275, doi:10.1029/2001JD000982.

Fiore, A. M., D. J. Jacob, R. Mathur, and R. V. Martin (2003a), Application of empirical orthogonal functions to evaluate ozone simulations with regional and global models, J. Geophys. Res., 108(D14), 4431, doi:10.1029/2002JD003151.

Fiore, A., D. J. Jacob, H. Liu, R. M. Yantosca, T. D. Fairlie, and Q. Li (2003b), Variability in surface ozone background over the United States: Implications for air quality policy, J. Geophys. Res., 108(D24), 4787, doi:10.1029/2003JD003855.

Gilliland, A. B., R. L. Dennis, S. J. Roselle, and T. E. Pierce (2003), Seasonal $\mathrm{NH}_{3}$ emission estimates for the eastern United States based on ammonium wet concentrations and an inverse modeling method, J. Geophys. Res., 108(D15), 4477, doi:10.1029/2002JD003063.

Gong, S. L., L. A. Barrie, and M. Lazare (2002), Canadian Aerosol Module (CAM): A size-segregated simulation of atmospheric aerosol processes for climated and air quality models: 2. Global sea-salt aerosol and its budgets, J. Geophys. Res., 107(D24), 4779, doi:10.1029/ 2001JD002004

Heald, C. L., et al. (2003), Asian outflow and trans-Pacific transport of carbon monoxide and ozone pollution: An integrated satellite, aircraft, and model perspective, J. Geophys. Res., 108(D24), 4804, doi:10.1029/ 2003JD003507.

Hirsch, R. M., and E. J. Gilroy (1984), Methods of fitting a straight line to data: Examples in water resources, Water Resour. Bull., 20, 705-711.

Husar, R. B., et al. (2001), Asian dust events of April 1998, J. Geophys. Res., 106(D16), 18,317-18,330. 
Intergovernmental Panel on Climate Change (IPCC) (2001), Special Report on Emissions Scenarios, edited by N. Nakicenovic, Cambridge Univ. Press, New York.

Jacob, D. J. (1986), Chemistry of OH in remote clouds and its role in the production of formic acid and peroxymonosulfate, J. Geophys. Res., 91(D9), 9807-9826.

Jacob, D. J. (2000), Heterogeneous chemistry and tropospheric ozone, Atmos. Environ., 34, 2131-2159.

Jacob, D. J., J. A. Logan, and P. P. Murti (1999), Effect of rising Asian emissions on surface ozone in the United States, Geophys. Res. Lett., 26(14), 2175-2178.

Jacob, D. J., J. H. Crawford, M. M. Kleb, V. S. Connors, R. J. Bendura, J. L. Raper, G. W. Sachse, J. C. Gille, L. Emmons, and C. L. Heald (2003), Transport and Chemical Evolution over the Pacific (TRACE-P) aircraft mission: Design, execution, and first results, J. Geophys. Res., 108(D20), 9000, doi:10.1029/2002JD003276.

Jaeglé, L., D. A. Jaffe, H. U. Price, P. Weiss-Penzias, P. I. Palmer, M. J. Evans, D. J. Jacob, and I. Bey (2003), Sources and budgets for CO and $\mathrm{O}_{3}$ in the northeastern Pacific during the spring of 2001: Results from the PHOBEA-II Experiment, J. Geophys. Res., 108(D20), 8802, doi:10.1029/2002JD003121.

Jaffe, D., et al. (1999), Transport of Asian air pollution to North America, Geophys. Res. Lett., 26(6), 711-714.

Jaffe, D., I. McKendry, T. Anderson, and H. Price (2003), Six 'new' episodes of trans-Pacific transport of air pollutants, Atmos. Environ., 37, $391-404$.

Jordan, C. E., J. E. Dibb, B. E. Anderson, and H. E. Fuelberg (2003), Uptake of nitrate and sulfate on dust aerosols during TRACE-P, J. Geophys. Res., 108(D21), 8817, doi:10.1029/2002JD003101.

Kettle, A. J., et al. (1999), A global database of sea surface dimethylsulfide (DMS) measurements and a procedure to predict sea surface DMS as a function of latitude, longitude, and month, Global Biogeochem. Cycles, 13(2), 399-444.

Kiley, C. M., et al. (2003), An intercomparison and evaluation of aircraftderived and simulated $\mathrm{CO}$ from seven chemical transport models during the TRACE-P experiment, J. Geophys. Res., 108(D21), 8819, doi:10.1029/2002JD003089.

Koike, M., et al. (2003), Export of anthropogenic reactive nitrogen and sulfur compounds from the east Asia region in spring, J. Geophys. Res., 108(D20), 8789, doi:10.1029/2002JD003284.

Kreidenweis, S. M., C. J. Walcek, G. Feingold, W. Gong, M. Z. Jacobson, C.-H. Kim, X. Liu, J. E. Penner, A. Nenes, and J. H. Seinfeld (2003), Modification of aerosol mass and size distribution due to aqueous-phase $\mathrm{SO}_{2}$ oxidation in clouds: Comparisons of several models, J. Geophys. Res., 108(D7), 4213, doi:10.1029/2002JD002697.

Lavery, T. F., C. M. Rogers, H. Kemp Howell, M. C. Burnett, C. A. Wanta, and M. O. Stewart (2002), Clean Air Status and Trends Network (CASTNet) 2001 Annual Report, Contract 68-D-98-112, 109 pp., U.S. Environ. Prot. Agency, Research Triangle Park, N. C.

$\mathrm{Li}, \mathrm{Q}$., et al. (2001), A tropospheric ozone maximum over the Middle East, Geophys. Res. Lett., 28(17), 3235-3238.

Li, Q., et al. (2002a), Transatlantic transport of pollution and its effects on surface ozone in Europe and North America, J. Geophys. Res., 107(D13), 4166, doi:10.1029/2001JD001422.

Li, Q., D. J. Jacob, T. D. Fairlie, H. Liu, R. V. Martin, and R. M. Yantosca (2002b), Stratospheric versus pollution influences on ozone at Bermuda: Reconciling past analyses, J. Geophys. Res., 107(D22), 4611, doi:10.1029/2002JD002138.

Li, Q., D. J. Jacob, R. Yantosca, C. Heald, H. Singh, M. Koike, Y. Zhao, G. W. Sachse, and D. Streets (2003), A global three-dimensional model analysis of the atmospheric budgets of $\mathrm{HCN}$ and $\mathrm{CH}_{3} \mathrm{CN}$ : Constraints from aircraft and ground measurements, J. Geophys. Res., 108(D21), 8827, doi:10.1029/2002JD003075.

Li, Q., D. J. Jacob, J. W. Munger, R. M. Yantosca, and D. D. Parrish (2004), Export of $\mathrm{NO}_{y}$ from the North American boundary layer: Reconciling aircraft observations and global model budgets, J. Geophys. Res., 109, D02313, doi:10.1029/2003JD004086.

Liss, P. S., and L. Merlivat (1986), Air-sea gas exchange rates: Introduction and synthesis, in The Role of Air-Sea Exchange in Geochemical Cycling, edited by P. Buat-Ménard, pp. 113-127, D. Reidel, Norwell, Mass.

Liu, H., D. J. Jacob, I. Bey, and R. M. Yantosca (2001), Constraints from ${ }^{210} \mathrm{~Pb}$ and ${ }^{7} \mathrm{Be}$ on wet deposition and transport in a global three-dimensional chemical tracer model driven by assimilated meteorological fields, J. Geophys. Res., 106(D11), 12,109-12,128.

Liu, H., D. J. Jacob, L. Y. Chan, S. J. Oltmans, I. Bey, R. M. Yantosca, J. M. Harris, B. N. Duncan, and R. V. Martin (2002), Sources of tropospheric ozone along the Asian Pacific Rim: An analysis of ozonesonde observations, J. Geophys. Res., 107(D21), 4573, doi:10.1029/ 2001JD002005.
Liu, H., D. J. Jacob, I. Bey, R. M. Yantosca, B. N. Duncan, and G. W. Sachse (2003), Transport pathways for Asian pollution outflow over the Pacific: Interannual and seasonal variations, J. Geophys. Res., 108(D20), 8786, doi:10.1029/2002JD003102.

Liu, H., D. J. Jacob, J. E. Dibb, A. M. Fiore, and R. M. Yantosca (2004), Constraints on the sources of tropospheric ozone from ${ }^{210} \mathrm{~Pb}-{ }^{7} \mathrm{Be}-\mathrm{O}_{3}$ correlations, J. Geophys. Res., 109, D07306, doi:10.1029/ 2003JD003988

Malm, W. C., J. F. Sisler, D. Huffman, R. A. Eldred, and T. A. Cahill (1994), Spatial and seasonal trends in particle concentration and optical extinction in the United States, J. Geophys. Res., 99(D1), 1347-1370.

Malm, W. C., M. L. Pitchford, M. Scruggs, J. F. Sisler, R. Ames, S. Copeland, K. A. Gebhart, and D. E. Day (2000), Spatial and Seasonal Patterns and Temporal Variability of Haze and its Consituents in the United States: Report III, 0737-5352-47, Coop. Inst. for Res. in the Atmos., Colo. State Univ., Fort Collins, Colo.

Mari, C., D. J. Jacob, and P. Bechtold (2000), Transport and scavenging of soluble gases in a deep convective cloud, J. Geophys. Res., 105(D17), $22,255-22,267$

Martin, R. V., et al. (2002), Interpretation of TOMS observations of tropical tropospheric ozone with a global model and in situ observations, J. Geophys. Res., 107(D18), 4351, doi:10.1029/2001JD001480.

Martin, R. V., D. J. Jacob, R. M. Yantosca, M. Chin, and P. Ginoux (2003), Global and regional decreases in tropospheric oxidants from photochemical effects of aerosols, J. Geophys. Res., 108(D3), 4097, doi:10.1029/ 2002JD002622.

Martin, S. T., H. M. Hung, R. J. Park, D. J. Jacob, R. J. D. Spurr, K. V. Chance, and M. Chin (2004), Effects of the physical state of tropospheric ammonium-sulfate nitrate particles on global aerosol direct radiative forcing, Atmos. Chem. Phys., 4, 183-214.

McKendry, I. G., J. P. Hacker, R. Stull, S. Sakiyama, D. Mignacca, and K. Reid (2001), Long-range transport of Asian dust to the Lower Fraser Valley, British Columbia, Canada, J. Geophys. Res., 106(D16), 18,36118,370 .

National Atmospheric Deposition Program (2002), National Atmospheric Deposition Program 2001 Annual Summary, NADP Data Rep. 2002-01, Ill. State Water Surv., Champaign, Ill.

Palmer, P. I., D. J. Jacob, D. B. A. Jones, C. L. Heald, R. M. Yantosca, J. A. Logan, G. W. Sachse, and D. G. Streets (2003), Inverting for emissions of carbon monoxide from Asia using aircraft observations over the western Pacific, J. Geophys. Res., 108(D21), 8828, doi:10.1029/2003JD003397.

Park, R. J., D. J. Jacob, M. Chin, and R. V. Martin (2003), Sources of carbonaceous aerosols over the United States and implications for natural visibility, J. Geophys. Res., 108(D12), 4355, doi:10.1029/ 2002JD003190.

Roelle, P. A., and V. P. Aneja (2002), Characterization of ammonia emissions from soils in the upper coastal plain, North Carolina, Atmos. Environ., 36, 1087-1097.

Seinfeld, J. H., and S. N. Pandis (1998), Atmospheric Chemistry and Physics: From Air Pollution to Climate Change, John Wiley, Hoboken, N. J.

Somerville, R. C. J., and L. A. Remer (1984), Cloud optical thickness feedbacks in the $\mathrm{CO}_{2}$ climate problem, J. Geophys. Res., 89(D6), 9668-9672.

Streets, D. G., et al. (2003), An inventory of gaseous and primary aerosol emissions in Asia in the year 2000, J. Geophys. Res., 108(D21), 8809, doi:10.1029/2002JD003093.

Sundqvist, H., E. Berge, and J. E. Kristiansson (1989), Condensation and cloud parameterization studies with a mesoscale numerical weather prediction model, Mon. Weather Rev., 117, 1641-1657.

Suntharalingam, P., D. J. Jacob, P. I. Palmer, J. A. Logan, R. M. Yantosca, Y. Xiao, M. J. Evans, D. G. Streets, S. L. Vay, and G. W. Sachse (2004), Improved quantification of Chinese carbon fluxes using $\mathrm{CO}_{2} / \mathrm{CO}$ correlations in Asian outflow, J. Geophys. Res., 109, doi:10.1029/ 2003JD004362, in press.

Tu, F. H., D. C. Thornton, A. R. Bandy, M.-S. Kim, G. Carmichael, Y. Tang, L. Thornhill, and G. Sachse (2003), Dynamics and transport of sulfur dioxide over the Yellow Sea during TRACE-P, J. Geophys. Res., 108(D20), 8790, doi:10.1029/2002JD003227.

United States Environmental Protection Agency (U.S. EPA) (2001), National Air Quality and Emissions Trends Report, 1999, EPA 454/ R-01-004, Off. of Air Qual. Plann. and Stand., Research Triangle Park, N. C.

United States Environmental Protection Agency (U.S. EPA) (2003), Guidance for Estimating Natural Visibility Conditions Under the Regional Haze Rule, EPA 454/B-03-005, Off. of Air Qual. Plann. and Stand., Research Triangle Park, N. C.

Vaughan, J. K., C. Claiborn, and D. Finn (2001), April 1998 Asian dust event over the Columbia Plateau, J. Geophys. Res., 106(D16), 18,38118,402 . 
Wang, Y., D. J. Jacob, and J. A. Logan (1998), Global simulation of tropospheric $\mathrm{O}_{3}-\mathrm{NO}_{\mathrm{x}}$-hydrocarbon chemistry: 1. Model formulation, J. Geophys. Res., 103(D9), 10,713-10,726.

Wesely, M. L. (1989), Parameterization of surface resistance to gaseous dry deposition in regional-scale numerical models, Atmos. Environ., 23 , $1293-1304$.

West, J., A. Ansari, and S. N. Pandis (1999), Marginal $\mathrm{PM}_{2.5}$-Nonlinear aerosol mass response to sulfate reductions, J. Air Waste Manage. Assoc., $49,1415-1424$.

Xiao, Y., D. J. Jacob, J. S. Wang, J. A. Logan, P. I. Palmer P. Suntharalingam, R. M. Yantosca, G. W. Sachse, D. R. Blake, and D. G. Streets (2004), Constraints on Asian and European sources of methane from $\mathrm{CH}_{4}-\mathrm{C}_{2} \mathrm{H}_{6}$-CO correlations in Asian outflow, J. Geophys. Res., 109, D15S16, doi:10.1029/2003JD004475.
Yevich, R., and J. A. Logan (2003), An assessment of biofuel use and burning of agricultural waste in the developing world, Global Biogeochem. Cycles, 17(4), 1095, doi:10.1029/2002GB001952.

M. Chin, NASA Goddard Space Flight Center, Code 916, Building 21 , Room C217, Greenbelt, MD 20771, USA. (chin@rondo.gsfc.nasa.gov)

B. D. Field, D. J. Jacob, R. J. Park, and R. M. Yantosca, Division of Engineering and Applied Sciences, Department of Earth and Planetary Sciences, Harvard University, 12 Oxford Street, Cambridge, MA 02138, USA. (bdf@io.harvard.edu; djj@io.harvard.edu; rjp@io.harvard.edu; bmy@io.harvard.edu) 


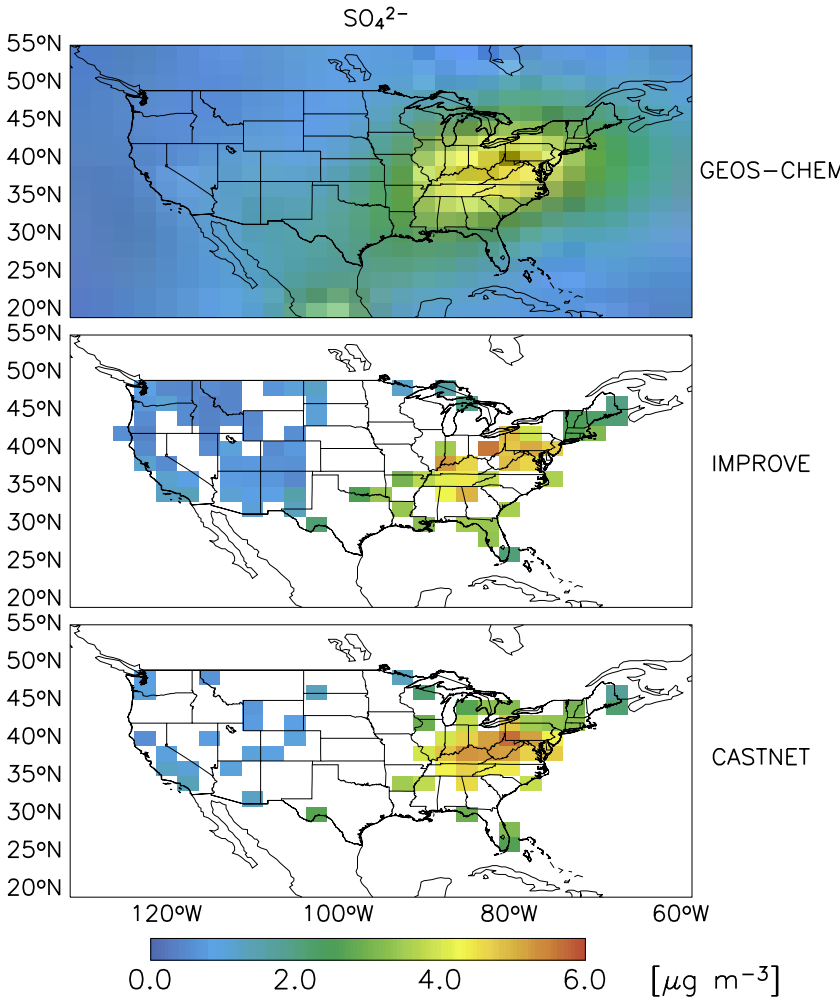

Figure 3. Annual mean concentrations of sulfate in surface air over the United States in 2001. (top) Results from the GEOS-CHEM model. (middle) Observations from the IMPROVE network averaged over the model $2^{\circ} \times$ $2.5^{\circ}$ grid. (bottom) Observations from the CASTNET network averaged over the model $2^{\circ} \times 2.5^{\circ}$ grid.

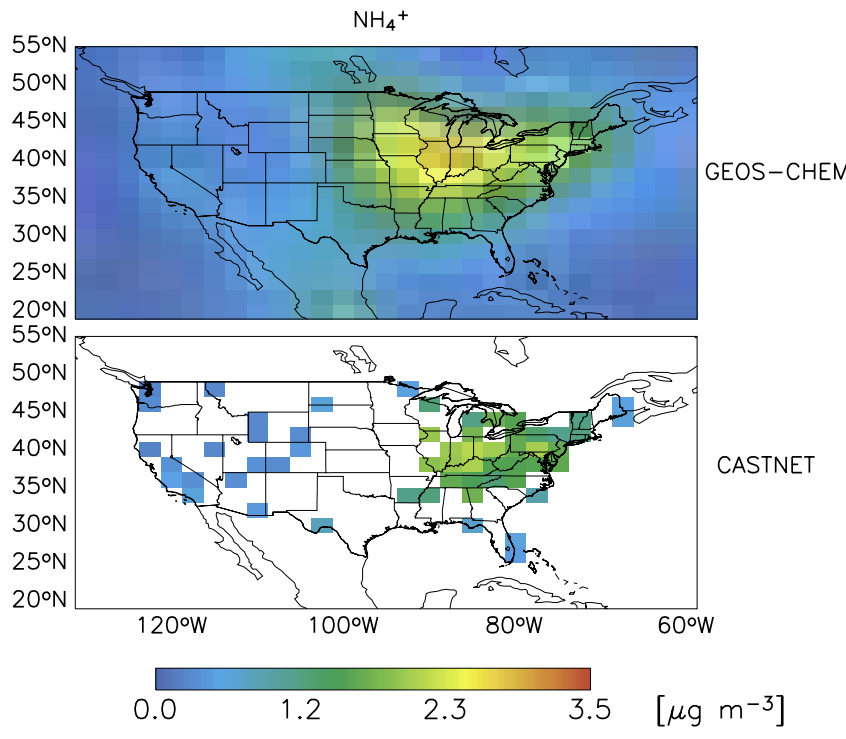

Figure 5. Annual mean concentrations of ammonium in surface air over the United States in 2001. (top) Results from the GEOS-CHEM model. (bottom) Observations from the CASTNET networks averaged over the model $2^{\circ} \times 2.5^{\circ}$ grid . (Ammonium is not measured at the IMPROVE sites.) 


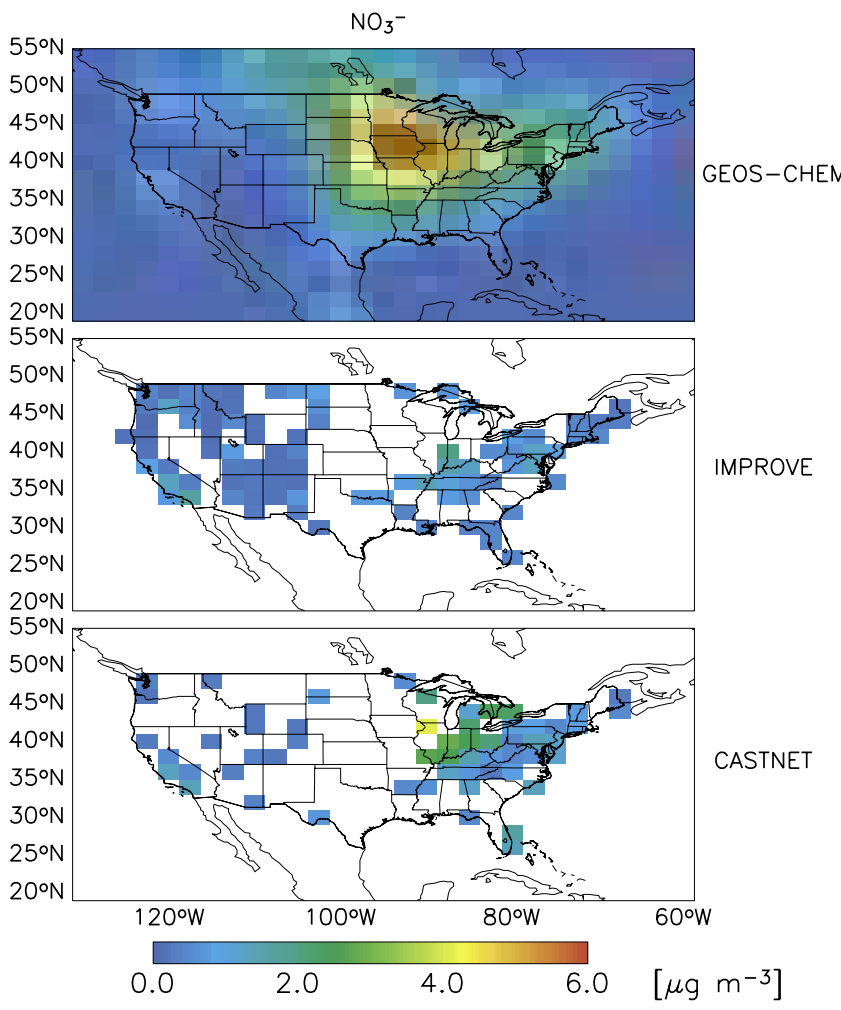

Figure 7. Same as in Figure 3 but for nitrate.

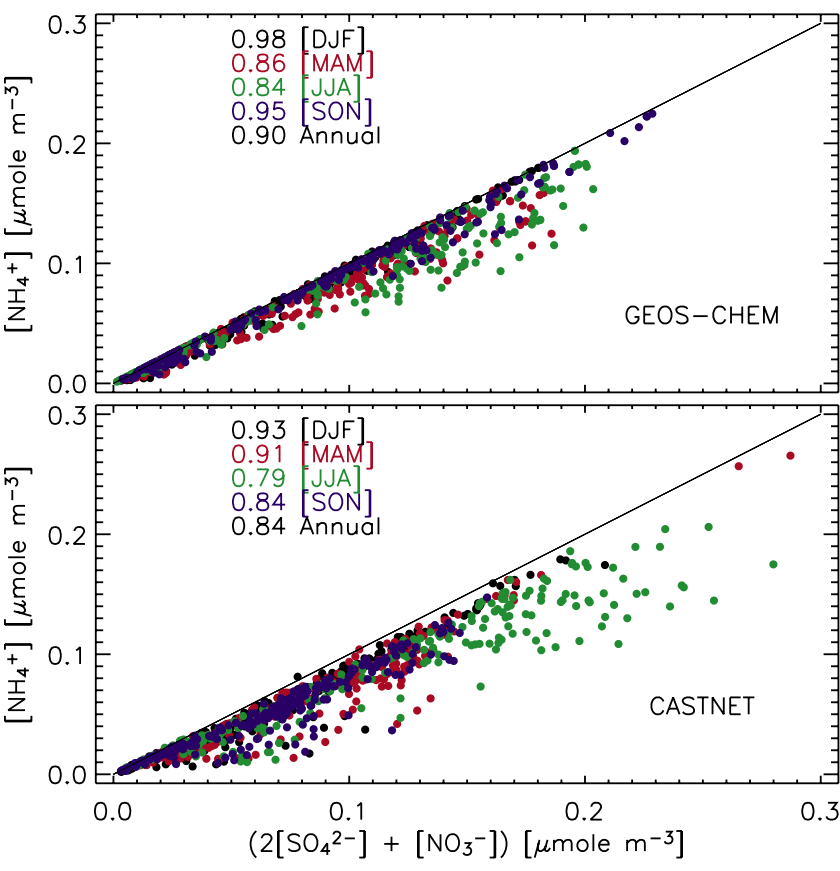

Figure 9. Scatterplot of seasonal mean $\left[\mathrm{NH}_{4}^{+}\right]$versus $\left(2\left[\mathrm{SO}_{4}^{2-}\right]+\left[\mathrm{NO}_{3}^{-}\right]\right)$at CASTNET sites in 2001 in the (top) GEOS-CHEM model and (bottom) observations. The reduced major axis regression slopes (given on the figure) indicate the degree of acid neutralization. 


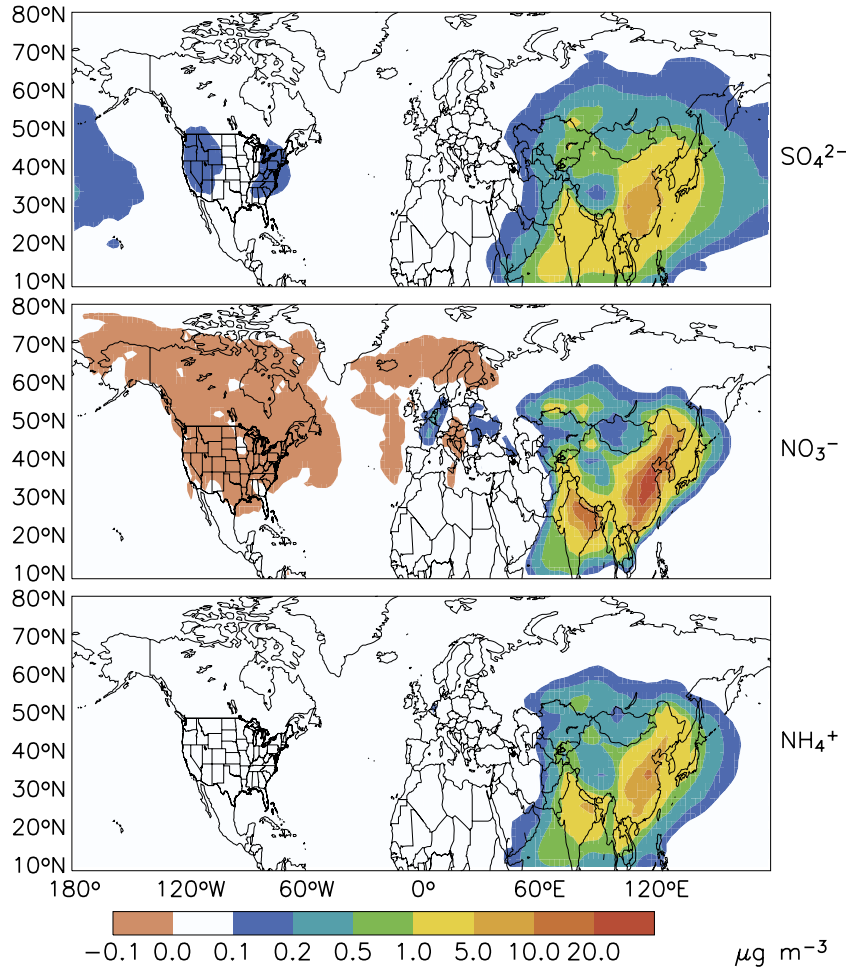

Figure 12a. Enhancements of sulfate-nitrate-ammonium aerosol concentrations in surface air due to anthropogenic emissions from Asia. Values are annual means for 2001, and they were obtained by difference between the standard model simulation and a sensitivity simulation with Asian anthropogenic sources shut off.

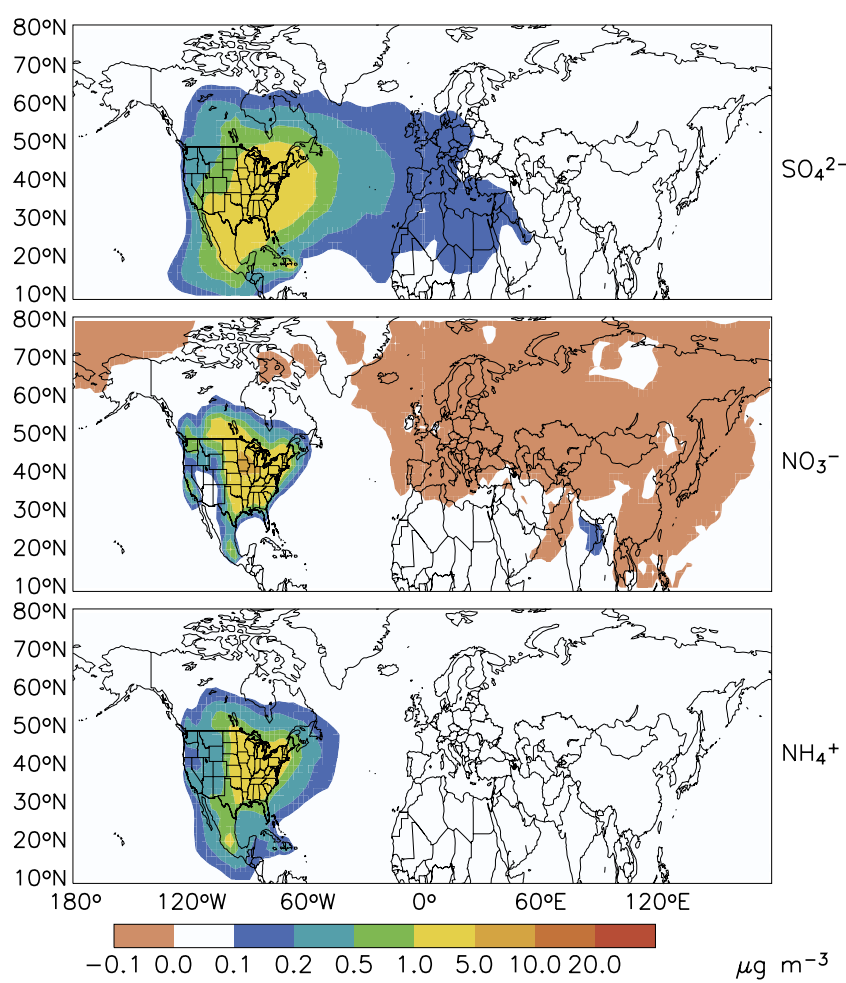

Figure 12b. Same as in Figure 12a but for anthropogenic emissions from North America. 